\title{
Janusz Skuczyński*
}

\section{Teatralny Toruń Krystyny Meissner}

DOI: http://dx.doi.org/10.12775/LC.2018.024

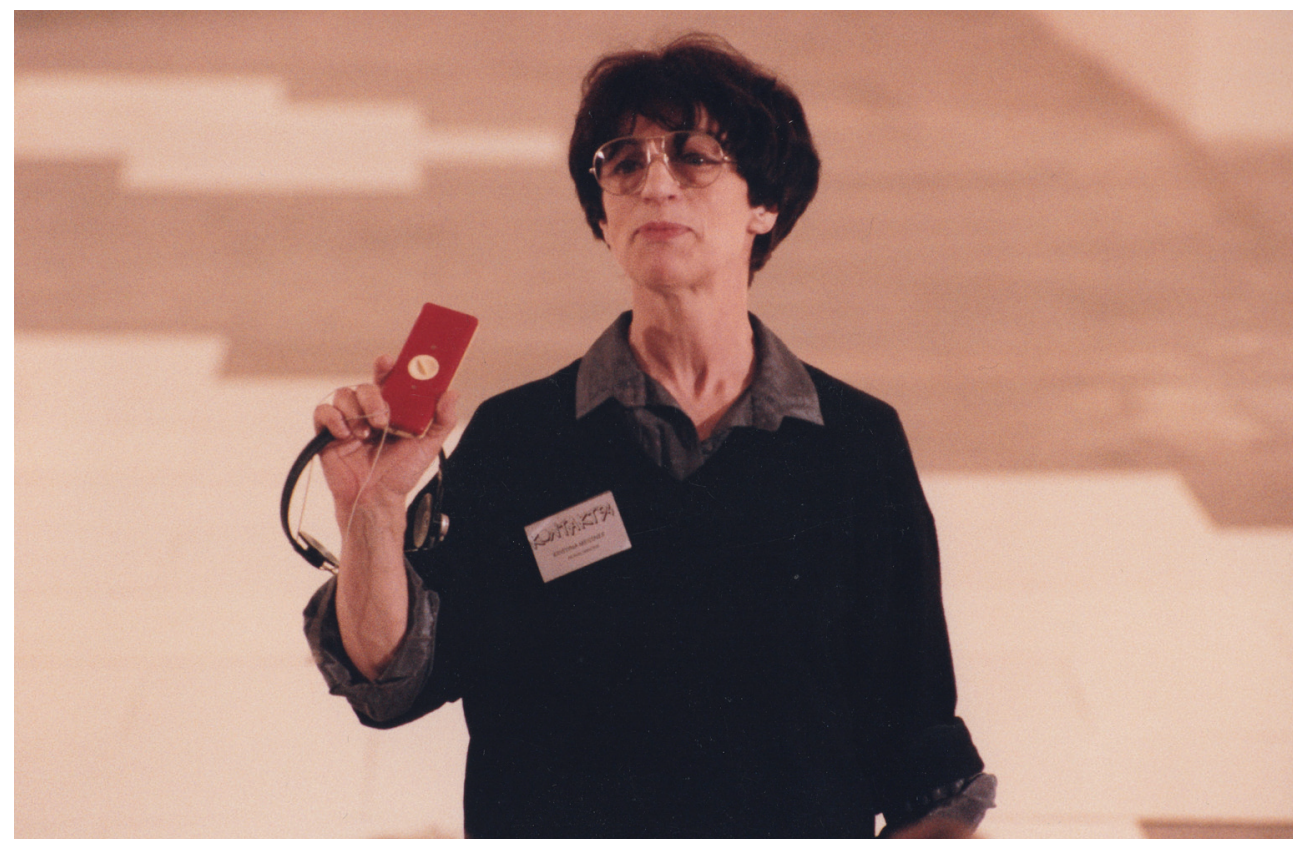

Krystyna Meissner

Fot. Wojtek Szabelski. Z archiwum Teatru im. W. Horzycy

a zasługi dla Torunia, który dzięki jej pracy twórczej i organizacyjnej stał się ważnym punktem na mapie teatralnej kraju, Krystyna Meissner otrzymała mosiężną płytę ze swoim nazwiskiem w Piernikowej Alei Gwiazd przed Dworem Artusa na Rynku Staromiejskim.

* Teatrolog i historyk literatury, profesor w Zakładzie Dramatu i Teatru Katedry Kulturoznawstwa Uniwersytetu Mikołaja Kopernika. Zainteresowania badawcze: dramat polski i niemiecki XIX wieku, historia teatru polskiego i europejskiego. E-mail: skujan@umk.pl. 
Pochodzi z rodziny lekarskiej. Ojciec Alfred Meissner był sławnym warszawskim chirurgiem, profesorem w Akademii Stomatologicznej. Jako drugie dziecko z siedmiorga była świadkiem likwidacji getta i powstania warszawskiego. Skończyła elitarne liceum sercanek w Pobiedziskach pod Poznaniem. Studiowała polonistykę na Uniwersytecie Warszawskim, gdzie spotkała się z kolegami: Jarosławem Abramowem-Newerlym, Andrzejem Jareckim, Andrzejem Drawiczem - twórcami STS-u, Ernestem Bryllem, a także Jerzym Koenigiem przyszłym krytykiem teatralnym. Potem dwukrotnie próbowała dostać się do łódzkiej szkoły filmowej. Ostatecznie ukończyła Wydział Reżyserii Teatralnej PWST w Warszawie, gdzie studiowała pod kierunkiem Bohdana Korzeniewskiego i Erwina Axera. Pierwszy raz na Zachód wyjechała w drugiej połowie lat 50., przebywała w Paryżu i Londynie, gdzie uczyła się języków, wieczorem pracowała, a za dnia uczestniczyła w próbach Petera Brooka oraz Jeana Vilara, twórcy jednego z największych festiwali teatralnych w Awinionie.

Debiutowała w Teatrze Ateneum w Warszawie trzema współczesnymi jednoaktówkami: Escurial Michela de Ghelderode’a, Samoobstuga Harolda Pintera i Na petnym morzu Sławomira Mrożka (1962). Następnie zaczęła współpracę reżyserską ze scenami w Białymstoku, Bydgoszczy, Gdańsku i Katowicach.

W Teatrze im. Wilama Horzycy w Toruniu pracowała już od roku 1968, przygotowując kolejno: Szkołę kobiet Wojciecha Bogusławskiego, Ich czworo Gabrieli Zapolskiej, Romulusa Wielkiego Friedricha Dürrenmatta ze znakomitą rolą Wiesława Drzewicza. Na toruńskim Festiwalu Teatrów Polski Północnej znalazła się już jej druga po debiucie praca reżyserska zrealizowana w Teatrze Dramatycznym im. Aleksandra Węgierki w Białymstoku (1963), źle zresztą po latach przez artystkę wspominana. Pierwszym sukcesem Meissner na toruńskim FTPP była Iwona, księżniczka Burgunda Witolda Gombrowicza, zrealizowana także w Toruniu za dyrekcji Marka Okopińskiego (1976). Dramat ten rozegrała w olbrzymiej szopce w stylu krakowskim, zbudowanej na planie teatru szekspirowskiego, zaludnionej przez manekiny oraz aktorów ustylizowanych na manekiny; wyjątkowej urody scenografię przygotował Andrzej Markiewicz. Na Kaliskich Spotkaniach Teatralnych (powstałych zresztą pod wpływem FTPP) triumfowało jej przedstawienie Życie jest snem Calderona de la Barca (1978). Później otrzymała główną nagrodę reżyserską na festiwalu w Toruniu za inscenizację w teatrze elbląskim Pluskwy Włodzimierza Majakowskiego (1980).

Swoją pozycję w polskim teatrze Krystyna Meissner budowała powoli. Pracując na scenach prowincjonalnych (terenowych, jak się wtedy mówiło), była też w latach 19701980 etatowym reżyserem w Teatrze Polskim w Warszawie, gdzie realizowała repertuar kameralny, obliczony na popis aktorski, i tzw. małą klasykę - włącznie z Moralnością pani Dulskiej Gabrieli Zapolskiej. Ażeby odsłonić ostrze wpisanej w utwór antymieszczańskiej satyry - stępionej przez całe lata grania tej „tragikomedii kołtuńskiej w trzech aktach” jako „obrazka z dawnych lat” - upomniała się o jej odniesienia współczesne. W roli tytułowej obsadziła Ninę Andrycz, kojarzącą się dotychczas z postaciami heroin dramatycznych i królowych, a która teraz jako pospolita mieszczka tyranizuje i demoralizuje całą rodzinę; służącą Hankę pokazała jako nowoczesne wcielenie Anieli Dulskiej. Krzysztof Pankiewicz dał całości plastyczny komentarz do dulszczyzny. Zaprojektował nie kolejny salon w pudełku sceny, ale ogromną przestrzeń otwartą, wychodzącą aż po ostatnie rzędy widowni i zapełnioną w bezładzie dziesiątkami mebli, bibelotów i przedmiotów z różnych epok, demonstracyjnie kiczowatych, przez które aktorzy cały czas musieli się przedzierać. Przedstawienie to stało się sensacją w kręgach stołecznej publiczności. Potem Meissner powtórzy ten zamysł ar- 
tystyczny w Teatrze im. Wilama Horzycy, w roli tytułowej obsadzając Grażynę Korsakow, aktorkę o podobnym do gwiazdy warszawskiej emploi. Po latach Krystyna Meissner stwierdziła, że w tym dopiero przedstawieniu z 1973 roku narodziła się „jako reżyser o samodzielnej twarzy" (Meissner: 1992b).

Drugą cezurą w pracy reżyserskiej Meissner stała się inscenizacja dramatu Tadeusza Micińskiego Pancernik Potiomkin, przygotowana w Teatrze im. Wandy Siemaszkowej w Rzeszowie. Była to dopiero druga, po słynnym wystawieniu Leona Schillera w warszawskim Teatrze im. Wojciecha Bogusławskiego, realizacja tego dramatu. O ile przedstawienie Moralności pani Dulskiej zostało uznane przez krytykę za ważny krok w uwspółcześnianiu dawnego repertuaru, tak tu szło o twórcze rozwijanie koncepcji teatru inscenizacji opartego na rodzimym poetyckim repertuarze romantycznym i neoromantycznym. O premierze było głośno już w całym kraju - jakkolwiek ten ekspresjonistyczny dramat o rewolucji 1905 roku w Rosji (w Odessie), przedstawionej przez autora nie tylko jako czyn zbrojny, ale i proces metafizyczny oraz moralny mający doprowadzić do przemiany duchowej całej ludzkości, nie mógł w tamtym czasie wybrzmieć do końca (zabrakło aktu piątego obrazującego klęskę rewolucji). Jak pisał po latach Roman Pawłowski: „jedni krytykują reżyser za zbyt reportażowy styl spektaklu, inni chwalą za świetne oddanie atmosfery rewolucyjnego chaosu" (Pawłowski 2003: 18).

Sukces rzeszowski ośmielił Krystynę Meissner do starań o stanowisko dyrektorki teatru. Jak powie po latach: „Chciałam mieć teatr, w którym sama zdecyduję, co grać” (ibid.). W roku 1980 objęła Teatr im. Leona Kruczkowskiego w Zielonej Górze, gdzie od paru lat wykruszał się skład osobowy, kierującym sceną brakowało energii w działaniu i wyraźnej osobowości artystycznej zdolnej przyciągnąć widzów na nowo do teatru. W czasie karnawału „Solidarności” wystawiła tam z jednej strony dramat Jerzego Żurka Sto rąk, sto sztyletów, z drugiej Czekając na Godota Samuela Becketta, a do tego jeszcze zaprosiła z monodramem opartym na prozie Tomasza Manna znaną aktorkę opozycjonistkę Halinę Mikołajską. Ale praca nie trwała długo. Za namową ustępującego dyrektora Teatru im. Wilama Horzycy, Marka Okopińskiego, zmęczonego kłopotami z zespołem w czasie stanu wojennego, Krystyna Meissner zdecydowała się w 1983 roku stanąć na czele tego teatru. Trwać będzie na tym stanowisku przez trzynaście i pół (prawie) sezonu.

\section{Rozpoznanie i zadania}

Swoją działalność dyrektorską Krystyna Meissner rozpoczęła od pytań o środowisko, w którym przyszło jej działać. Jak wyznaje w rozmowie ze stołeczną dziennikarką: „Środowisko w Toruniu jest bardzo zróżnicowane; jest tu bardzo wyrobiona inteligencja, środowisko uniwersyteckie, ale także zasiedziałe, stabilne, powleczone patyną tradycji mieszczaństwo, którego głównym motorem napędowym ku sztuce jest stale jeszcze snobizm”. Zaraz przy tym zarzeka się: „To nie stwierdzenie pejoratywne, tylko fakt, zanotowany bezstronnie i obiektywnie, bez poddawania go jakimkolwiek ocenom”. A poza tym wyróżnia jeszcze „publiczność robotniczą”, dodając od razu: „Bardzo nie lubię tego określenia, bo nie jest w pełni adekwatne do swej treści - powiedzmy więc, że publiczność rekrutująca się z ludzi prostych, ludzi, których potrzeby kulturalne jeszcze drzemią” (Hofman 1985: 12-13). 
Ta nieomal socjologiczna analiza potencjalnej widowni odsłania bliską poczucia misji powagę w traktowaniu przez Meissner swojej roli w mieście niedużym i monoteatralnym (wyłączając działający też w Toruniu Teatr Lalki i Aktora „Baj Pomorski”).

Drogą tych rozpoznań dociera następnie do określenia funkcji swojego teatru. „Stoi (on) w samym centrum miasta, nieopodal ratusza. Mógłby więc stać się ośrodkiem życia towarzyskiego w Toruniu”. Znaczy to dla niej, że w widzach trzeba najpierw obudzić

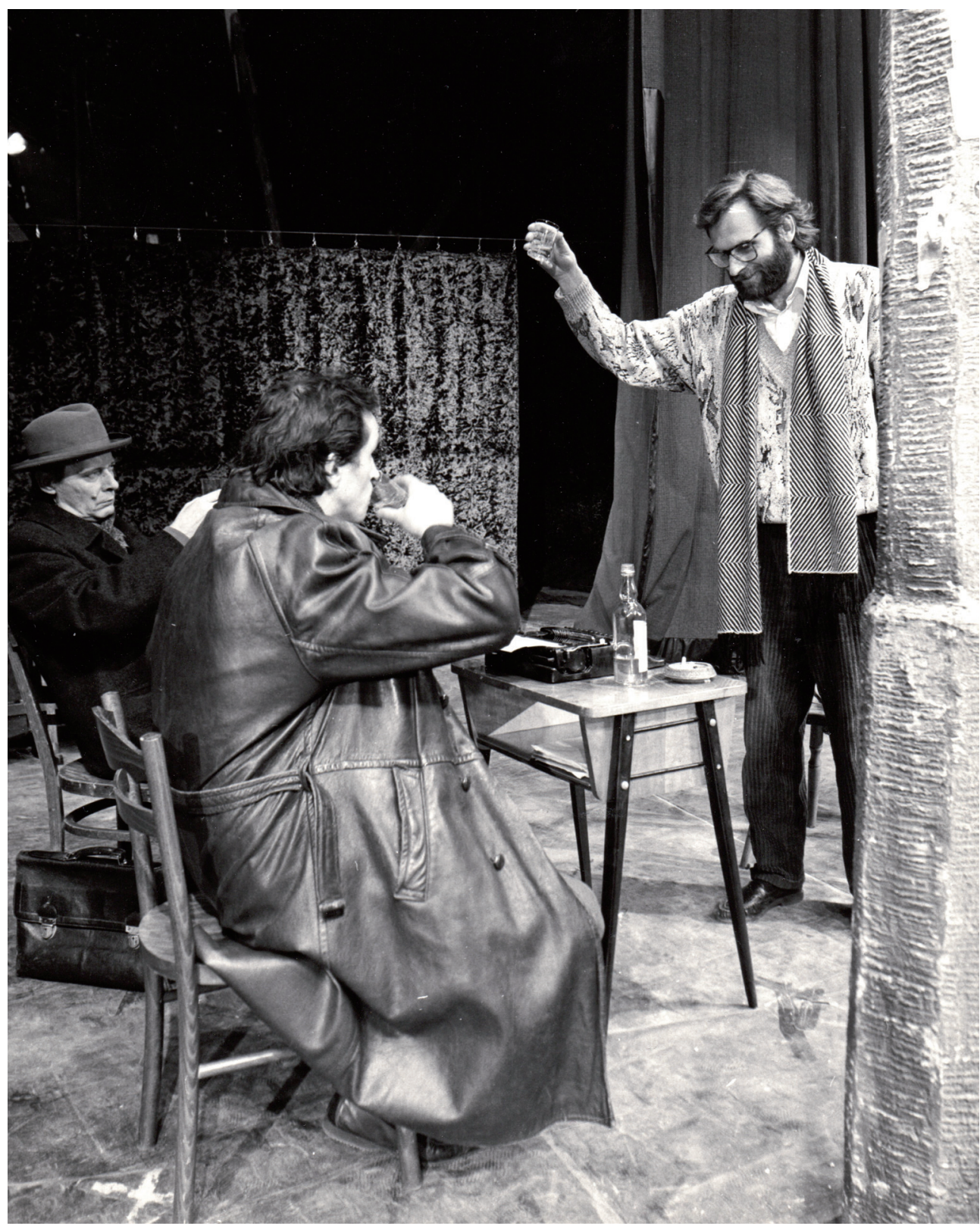

Wieczór polski (Mata apokalipsa) w reż. Krystyny Meissner (od lewej: Wojciech Szostak Hubert, działacz opozycji, od prawej: Ildefons Stachowiak - Ja, bohater) Fot. Stanisław Wojciech Reszkiewicz. Z archiwum Teatru im. W. Horzycy 
ciekawość „wobec siebie i wobec sztuki”. Dla twórców teatru ma to oznaczać, że „jedynym wyjściem w moim teatrze jest profesjonalizm [...], pojęty bardzo rygorystycznie. Aktor musi czuć odpowiedzialność za swoje pojawienie się na scenie. To nie chodzi - stwierdza Krystyna Meissner - o lepsze czy gorsze zagranie roli, ale o prawdziwość, o mówienie od siebie, o wiarygodność”. A kończy ten fragment wypowiedzi zdaniem: „Chcę stworzyć zespół, który połączy wspólne myślenie o sprawach najważniejszych, również o etyce zawodowej”. Ale też zaraz się mityguje: „Stworzenie takiego teatru i takiego zespołu w [...] biurokratycznym gorsecie naszej codzienności wydaje mi się tyleż frapujące, co niemożliwe”, gdyż „realne jest to tylko w naturalnie formującej się grupie. Jak u Grotowskiego, jak u Kantora, jak swego czasu u Szajny...”. W tej sytuacji, balansując między tym, co możliwe i niemożliwe, cele swej pracy artystycznej określi ostatecznie skromniej: pragnie „utrafić w to, co w ludziach; to co w człowieku. Dzisiaj. Teraz. Tutaj. To jedyna droga teatru ku publiczności” (Hofman 1985: 12-13).

\section{Repertuar współczesny i klasyczny}

Swoją dyrekcję Krystyna Meissner zainaugurowała premierą reżyserowanej przez siebie już wcześniej Kartoteki Tadeusza Różewicza. Spektakl otwierały słowa: „jesteśmy dzisiaj świadkami wstępnego stadium trzeciej wojny światowej”. Cała akcja sprzed katastrofy rozgrywa się na teatralnej scenie mieszczącej zarówno aktorów, jak i widzów. Są oni uczestnikami dyskoteki (scenografia Aleksandry Semenowicz), symbolu agresywności kultury młodzieżowej wypełniającej niemal bez reszty bojkotowane wówczas przez środowiska artystyczne środki masowego przekazu. Bohater grany przez Piotra Chudzińskiego mierzy się nie z pytaniem o sens działania, lecz o jego możliwości, uosabia politycznie wówczas aktualny problem emigracji wewnętrznej. Krystyna Meissner powiedziała: „Tak, to było ostre wejście. Wiedziałam, że muszę sprowokować spojrzenie na siebie jak największej liczby osób, zaznaczyć, że coś się stało: zmiana dyrekcji, zmiana kierunku myślenia o teatrze” (Meissner 1992a).

Za Kartoteka poszły trzy inne dramaty Różewicza, realizowane przez zaproszonych do współpracy reżyserów: Stara kobieta wysiaduje w reżyserii i scenografii Teresy Działak (1988), Białe małżeństwo w reżyserii Jana Maciejowskiego (1991), wielokrotnego laureata FTPP, któremu udało się „przebić” przez skandalizujący i frywolny erotyzm utworu w stronę stworzenia „wielkiego” dramatu dojrzewania i jednostkowej tożsamości, oraz Grupa Laokoona w reżyserii Jana Różewicza (1994), syna poety. Przez wiele lat niegrany w Toruniu autor znalazł swoją stosowną do rangi twórczości reprezentację. Z dramatów Sławomira Mrożka - drugiego wtedy co do znaczenia autora w polskim teatrze - zagrano dwie jednoaktówki Striptease i Karol w reżyserii aktora Teatru Horzycy, Piotra Chudzińskiego (1983) oraz prapremierę Wyspy róż w reżyserii Grzegorza Stanisławiaka (1989). Był to jeden z dwu scenariuszy, na podstawie którego przebywający na Zachodzie pisarz nakręcił (o czym w Polsce było wtedy cicho) film łączący problematykę polityczną i egzystencjalną; scenariusz ten nie wytrzymał jednak próby teatru. Ponadto na scenie znalazł się scenariusz filmowy dwójki autorów: Krzysztofa Zanussiego i Edwarda Żebrowskiego Miłosierdzie płatne z góry (1987) w reżyserii Stefana Szacikowskiego, zagrany na jubileusz czterdziestolecia pracy aktorskiej Grażyny Korsakow. 
Wśród autorów dramatycznych mniejszych rangą w repertuarze znalazły się najważniejsze ich utwory. Wystawiono sztukę Ireneusza Iredyńskiego Żegnaj, Judaszu w reżyserii znowu toruńskiego aktora Stefana Knothego (1984). Bohdana Drozdowskiego Kondukt, dramat ten zasłynął wcześniej za sprawą realizacji Jerzego Krassowskiego w nowohuckim Teatrze Ludowym, a następnie - Marka Okopińskiego w Zielonej Górze, który po latach przygotował go też w Teatrze im. Wilama Horzycy (1984). Spośród licznych sztuk Stanisława Grochowiaka sięgnięto do Chłopców w reżyserskim ujęciu Ryszarda Bera (1985), specjalisty od filmowych adaptacji twórczości tego autora. Doszły ponadto dwie pozycje Bogusława Schaeffera: w reżyserii Mikołaja Grabowskiego, który wypromował w ogóle tę dramaturgię na polskich scenach, Kwartet dla czterech aktorów oparty na zabawnych scenkach muzycznych, dialogowych, wizualnych, parateatralnych (1987), oraz Audiencja 3 w reżyserii i scenografii Bogusława Semotiuka (1993). Wreszcie znalazło się miejsce dla czysto rozrywkowej Romancy Jacka Chmielnika w reżyserii Waldemara Wilhelma (1986).

Współczesna dramaturgia obca była realizowana za dyrekcji Krystyny Meissner głównie przez młodych reżyserów, o których mowa będzie później. Teraz dodajmy tylko, że w repertuarze znalazła się farsa Michaela Frayna Czego nie widać w reżyserii Wojciecha Zeidlera (1989), przedstawienie dla widowni zarówno dziecięcej, jak i dorosłej - Antoine de SaintExupery'ego Mały książę w reżyserii znanej aktorki Magdy Teresy Wójcik (1992), wreszcie podejmująca problematykę religijną (na wzór hiszpańskich barokowych autos sacramentales) komedia Ariano Suassuny Testament psa, czyli historia o Miłosiernej w reżyserii znowu Bogusława Semotiuka (1993).

Nawiązanie przez teatr stosunków partnerskich z Getyngą (miasto umowę podpisało już w 1978 roku) zaowocowało prapremierą sztuki Güntera Grassa Powódź, w której tytuł sygnuje czas wywołanej przez nazistów katastrofy wojennej i zarysowany w utworze obraz powojennego społeczeństwa niemieckiego postawionego w stan oskarżenia; przedstawienie wyreżyserował Józef Skwark, a scenograf Krzysztof Pankiewicz zaproponował imponującą konstrukcję sceniczną, która była projekcją domu, biblijnej arki, w końcu - drzewa złego i dobrego z Księgi Rodzaju. Potem w ramach polsko-niemieckiej współpracy teatru Krystyna Meissner wyreżyserowała dramat Tankreda Dorsta Fernando Krapp napisat do mnie ten list ze scenografią Aleksandry Semenowicz (1994). Co zaś ważniejsze: obie przygotowały adaptację powieści austriackiego pisarza Roberta Musila Niepokoje wychowanka Törlessa (1993). W ramach kilku planów scenicznych, w tym na pomysłowo rozwiązanym strychu (z czerwonym suknem wybitą komórką), zostały zainscenizowane wyobrażenia i lęki tytułowego bohatera w okresie dojrzewania, konfrontowane z obrazem rzeczywistości sprzed I wojny światowej. Pozwoliło to dać w przedstawieniu wyraz przekonaniu Musila o dwoistości i niepojętości natury człowieka, a jednocześnie ujawnić czysto teatralny, autonomiczny charakter kształtowanej w ten sposób rzeczywistości w teatrze. Scenariusz widowiska obejmującego siedemnaście scen granych bez przerwy napisała Meissner; akcję w powieści rozgrywającą się właściwie tylko między czterema uczniami szkoły kadetów przetworzyła w pełnospektaklowy, stosunkowo szeroko sfabularyzowany swoisty traktat o „sprawie Baziniego” oraz z ogromną kulturą potraktowała zawarty w powieści z 1906 roku temat sadomasochistycznych ekscesów i seansów, antycypujący czasy nazizmu.

Zainicjowane na początku lat 90. kontakty z Filadelfią (wcześniej były to już miasta siostrzane) zaowocowały dwoma przedstawieniami jednoaktówek w reżyserii dyrektorki: Amerykański blues (1992) oraz Amerykańskie bajki dla dorostych (1995). 
Klasykę dramatu traktowała Meissner w dwóch porządkach; z jednej strony pozycje obowiązujące, należące do podstaw edukacji tak szkolnej, jak wyższej, z drugiej - będące wyrazem indywidualnych predylekcji dyrektorki i zapraszanych przez nią twórców. Zostały zatem wystawione w Toruniu m.in. Aleksandra Fredry Śluby panieńskie (reż. Józef Skwark, 1987), Romeo i Julia Szekspira (reż. Bogusław Kierc, 1988), Biesy Fiodora Dostojewskiego (reż. Jan Maciejowski, 1993), Wariatka $z$ Chaillot Jeana Giraudoux (reż. Jan Błeszyński, 1992), Przygody dobrego wojaka Szwejka Jaroslava Haška (reż. Waldemar Wilhelm, 1984).

\section{Teatr muzyczny}

W drugiej grupie znalazły się sztuki muzyczne. Prezentując repertuar swojego teatru, Krystyna Meissner podkreśliła, że „toruńska publiczność przepada za teatrem muzycznym. Wynika to z historycznych uwarunkowań tradycji ziem zaboru pruskiego". I deklarowała: „operetki nie będzie, ale elementy teatru muzycznego - tak” (Meissner 1983). Na afiszu pojawiły się wodewile mające w teatrze dramatycznym stosunkowo długą tradycję wystawień. Andrzej Rozhin jako reżyser Cudu mniemanego, czyli Krakowiaków i Górali Wojciecha Bogusławskiego i Jana Stefaniego wprost do niej nawiązał premierą z 1 marca 1994 roku, dokładnie w dwusetną rocznicę prapremiery warszawskiej. $\mathrm{Z}$ tego też powodu pojawiły się w spektaklu nawiązania do historii polskiego teatru, stylizowane dekoracje, konwencjonalna mimika aktorów z ówczesnego teatru iluzjonistycznego, a całość wieńczyły precyzyjnie skomponowane żywiołowe sceny zbiorowe, w których obok aktorów występowali członkowie zespołów pieśni i tańca „Młody Toruń” i „Toruniacy” oraz grający na żywo muzycy Toruńskiej Orkiestry Kameralnej pod dyrekcją Włodzimierza Szymańskiego.

Drugim wodewilem wystawianym w Toruniu był Żotnierz królowej Madagaskaru (na podstawie farsy Stanisława Dobrzańskiego, z muzyką Tadeusza Sygietyńskiego) wyreżyserowany przez Piotra Cieplaka. Lekkość, wdzięk i dynamika akcji była wspierana tymi samymi walorami piosenek (na czele z utworem Lat dwadzieścia miat mój dziad), łączonych z walczykami i kankanem. Muzykę grała na żywo Toruńska Orkiestra Kameralna pod dyrekcją Warcisława Kunca i Stanisława Welanyka. Oba przedstawienia, za każdym razem gorąco oklaskiwane (nie tylko w Toruniu), ze względu na wysokie koszty eksploatacji wcześnie zeszły $z$ afisza.

Nie zdarzyło się chyba wcześniej, aby w jednym teatrze dramatycznym za jednej dyrekcji została wystawiona najpierw opera balladowa (powstała w XVIII wieku na Wyspach Brytyjskich ze sprzeciwu wobec opery włoskiej), a następnie jej nowoczesna XX-wieczna przeróbka. Stało się tak w Toruniu, gdzie Krystyna Meissner wprowadziła do repertuaru Operę żebracza Johna Gaya i Johanna Pepuscha w reżyserii młodego artysty Wojciecha Maryańskiego (1984), a następnie Operę za trzy grosze Bertolta Brechta i Kurta Weilla (1995) w realizacji Marty Stebnickiej i ze scenografią Barbary Hanickiej. Twórcy Opery żebraczej, w tym Krzysztof Kelm jako scenograf, zrezygnowali z akcentów satyryczno-ideologicznych wpisanych w libretto i skupili się na wątkach miłosno-erotycznych. Aktorzy w kostiumach ahistorycznych rozwijali - jak pisała recenzentka - „sceny komponowane techniką kolażu, w których mieściły się pomysły rodem z kinowej burleski, estradowe piosenkarstwo" i sporo zrytmizowanego ruchu, tańca i stepowania (Oleradzka 1984). 
Marta Stebnicka, zanim zainscenizowała Operę za trzy grosze, zrealizowała Piosenki Georgesa Brassensa (1991), a potem Piosenki przed trybunatem Pierre-Jean de Bérangera (1993). Trzecim przedstawieniem z kręgu teatru piosenki był Wieczór z Tuwimem (1987) w reżyserii Zbigniewa Rymarza.

Béranger był bardem paryskiej ulicy z pierwszej połowy XIX stulecia, znanym nawet Mickiewiczowi, śpiewał ballady, piosenki o charakterze plebejskim, satyryczne kuplety wymierzone przeciw możnym i władzy. W spektaklu oprócz piosenek wykorzystano autentyczne materiały na temat czasów Restauracji i dwu procesów wytoczonych Bérangerowi. Muzykę skomponowali Ewa Kornecka i Andrzej Czopik, inspirując się współczesną piosenką wojskową, kabaretową i poetycką. Rozmach inscenizacyjny przedstawienia sprawil, że Piosenki przed trybunatem zaprezentowano m.in. na festiwalu „Kontakt” w 1994 roku, gdzie otrzymały nagrodę dziennikarzy, a międzynarodowe jury wyraziło żal, że nie znalazły się w konkursie.

Do Opery za trzy grosze Marta Stebnicka wprowadziła postać Dyrygenta i zainscenizowała „teatr w teatrze, rozpinając jego formułę między cyrkową konwencją, bliską sztuce jarmarcznej czy podwórkowej a kabaretem” - jak pisał recenzent. I dodał: „Nie stosuje żadnych ułatwień; ani rytmicznych, ani melodycznych" (Churski 1996). Z granych na żywo, przez siedmiu muzyków ubranych w stroje o cyrkowej proweniencji, kompozycji muzycznych Kurta Weilla wydobyła ich chropawy charakter, „pełen dysonansów, zgrzytów, atonalności" w melodii i harmonii (ibid.). Dlatego po Piosenkach przed trybunatem, w których Marta Stebnicka zaprezentowała teatr oddziałujący na zmysły i emocje widzów, Operę za trzy grosze przyjęto z rezerwą i zawodem.

Spektaklem należącym do kręgu piosenki był jeszcze Weill (1989), z jego muzyką i tekstami songów Bertolta Brechta. A ponadto Złota różdżka, czyli wierszyki zastraszające według Heinricha Hoffmanna i Stanisława Jachowicza (i innych), z muzyką Marka Materny, w reżyserii Jerzego Bielunasa (1992). Po wodewilu, operze balladowej, musicalu i teatrze piosenki pora na operę, która spośród gatunków teatru muzycznego interesowała Krystynę Meissner akurat najbardziej - nie tylko jako dyrektorkę, ale i inscenizatorkę. Najambitniej pomyślanym przedsięwzięciem Meissner w tym zakresie było przedstawienie Orfeusza ze scenografią Krzysztofa Pankiewicza (1991). Spektakl opierał się na kantacie barokowej Louisa Nicolasa Clerambaulta i poemacie Tristana L'Hermite’a; przygotowano go również we francuskiej wersji językowej, ale większego rezonansu nie wywołał. Podobnie się stało z długo przygotowywaną Operetka Witolda Gombrowicza ze scenografią Krzysztofa Pankiewicza (1988). Reżyserka zbagatelizowała wręcz operetkowe konwencje, w jakie została wpisana przez autora jego tragikomedia. Scenograf wykreował na scenie offenbachiady, ale potem w akcie trzecim nieoczekiwanie oboje przeszli do szekspiriady, do Szekspira z jego Wielkim Mechanizmem Historii. Finałowa apoteoza nagości trafiła w konsekwencji w myślową pustkę. Skomponowana przez Joannę Wnuk-Nazarową oprawa muzyczna była bliska „klasycznemu stylowi dawnej wiedeńskiej operetki” - jak życzył sobie Gombrowicz, ale w całości okazała się mało zróżnicowana. Grana była na żywo przez Toruńską Orkiestrę Kameralną pod kierownictwem Stanisława Welanyka. Sukcesem kończyły się natomiast adaptacje oper przeznaczone dla widowni młodej i najmłodszej, włączone w cały cykl przedstawień muzycznych dla dzieci obejmujący aż osiem premier.

Scenariusz do Czarodziejskiego fletu przygotowała Meissner jako „opowieść według opery Wolfganga Amadeusza Mozarta” (1985). Drogę młodego księcia ku miłości, wiedzy 
i poznaniu uprościła pod względem treści i formy, tak, by mogło ono przede wszystkim emocjonować i bawić najmłodszych widzów. Krzysztof Pankiewicz przygotował oprawę sceniczną oddającą charakter i nastrój zaczarowanej krainy; zwiewność malowanych na tiulach dekoracji dopełniały efekty użycia maszynerii teatralnej, która wybrzmiewała grzmotami, wybuchami ognia, świstem wiatru. W kostiumach wydobywano baśniowość oraz świat rokokowych figurek porcelanowych. Głównym zadaniem reżysera Janusza Pieczuro, wywodzącego się z wrocławskiego Teatru Pantomimy Henryka Tomaszewskiego, było dostosowanie opery do możliwości sceny dramatycznej: belcanto zostało zastąpione wokalem aktorów bądź aktorską gestyką ilustrującą podawaną z taśm i płyt archiwalnych muzykę Mozarta w wykonaniu filharmoników berlińskich.

Czarodziejski flet zaznajamiał widzów głównie z fabułą opery. Twórcy inscenizacji Kopciuszka Gioachino Rossiniego, reżyser Wojciech Kępczyński i Małgorzata Treuttler jako scenograf (1990), poszli w innym kierunku. Bohaterem spektaklu uczynili muzykę - poczynając od tego, że wprowadzili jako bohatera postać kompozytora, dla którego dzieje Kopciuszka z popularnej baśni są „tylko” zobrazowaniem historii ukrytej w muzyce. Na scenie znajdujemy obrazy, zdarzenia, wątki wyprowadzone z kompozycji muzycznej, której nuty są widoczne na tiulowej kurtynie jako znaki graficzne. Wkraczający na plan akcji w rytmie muzyki członkowie orkiestry ubrani są w czarne togi, wykończone biało przy szyi i tego koloru mają buty, przez co w delikatnym świetle przenikającym przez tiule kojarzyli się z ożywioną klawiaturą instrumentu muzycznego. Przydano im też bajkowe instrumenty oraz otoczenie. Kominek wyglądem przypominał lirę, ściany i kolumny barokowej sali upodobniono do organów, konie zaprzężone do karety to dwa klucze wiolinowe. Aktorzy recytowali tekst przy akompaniamencie klawesynu, dopełnianego o nagrania orkiestry symfonicznej i śpiewaków operowych. W scenach zbiorowych aktorzy w pięknych strojach dam, księżniczek, pasterek, arlekinów, z perukami na głowach i upudrowanymi twarzami przypominali lalki, którymi porusza muzyka.

Inne spektakle operowe dla dzieci łączyły ze sobą z jednej strony demonstrację, przedstawienie fabuły, z drugiej - muzyki, „czystego teatru”, różnie tylko i w rozmaitych proporcjach. Królowa elfów z muzyką XVII-wiecznego angielskiego kompozytora Henry’ego Purcella w reżyserii Krystyny Meissner i ze scenografią Krzysztofa Pankiewicza (1982) wykorzystała wątek komedii Szekspira Sen nocy letniej, w której znalazła się „najsmutniejsza komedia o najokrutniejszej śmierci Pyrama i Tyzbe”. Przedstawienie Piotruś, kaczka i wilk w reżyserii Romany Próchnickiej (1986) opierało się na bajce symfonicznej Sergiusza Prokofiewa, z tekstami Ewy Lipskiej; materia literacka okazała się zbyt wątła, by udźwignąć muzykę. Powstały dwa przedstawienia do muzyki baletowej Piotra Czajkowskiego: Dziadka do orzechów w reżyserii Piotra Czarnoty (1989) oraz Jeziora łabędziego (zatytułowanego Zaczarowane jezioro) w reżyserii i choreografii Władysława Janickiego (1995). Krystyna Meissner i Aleksandra Semenowicz jako autorka oprawy scenicznej zrealizowały Historię żotnierza Igora Strawińskiego (1992), sięgając po muzykę do libretta Charlesa Ferdinanda Razuzema, która wytyczała drogi rozwoju całej XX-wiecznej twórczości operowej i symfonicznej; na podstawach tej muzyki przedstawiły wątek faustyczny w konwencji bliskiego im teatru jarmarcznego. Spektakl z dużym powodzeniem gościł za granicą. Wreszcie para twórców Kopciuszka, tj. Wojciech Kępczyński i Małgorzata Treuttler, zrealizowała Byka na dachu opartego na balecie Dariusza Milhauda z librettem Jeana Cocteau (1992). 


\section{Repertuar rosyjski i konteksty}

Na Festiwalu Teatrów Polski Północnej w roku 1980 zabłysnęła Krystyna Meissner realizacją Łaźni Włodzimierza Majakowskiego w elbląskim teatrze. Zderzyła powagę akcentów politycznych z zaproszeniem widzów do wspólnej zabawy teatralnej, rozpoczętej wraz $\mathrm{z}$ wejściem na scenę strażackiej orkiestry (przygrywającej także w przerwie spektaklu), z rozrzucaniem na widownię ulotek „komitetu przeciwalkoholowego”. Całość gry z widzem dopełniała obecność kamer telewizyjnych i telewizorów oraz zawieszony nad sceną „monter” z datami, który pozwalał łączyć dziejące się w teatrze wydarzenia z aktualnym czasem trwania przedstawienia. Urządzenia naszej epoki telewizyjnej stały się trafnym symbolem przyszłości, której kształtu dociekał Majakowski w Łaźni powstałej pół wieku wcześniej.

Już w Toruniu Meissner wystawiła z Aleksandrą Semenowicz spektakl Teatr to świątynia oparty na dwóch utworach Michała Bułhakowa, dramacie Szkartatna wyspa i Powieści teatralnej. W ramach organizujących spektakl trzech planów kompozycyjnych zaproponowała widzom „wszystko, czym scena dysponuje” - jak pisała recenzentka: „Od całej gamy różnorodnych konwencji, przez sztukę iluzji teatralnej, do efektów najprostszych - „cyrku i fajerwerków”, czyli „wybuchu wulkanu, muzyki i angielskich majtków”. A po drodze były jeszcze: tańczące baletnice, „wyryczany w coraz to innej tonacji” początek monologu Hamleta, „dekoratorskie bezguście”, „intrygi i intryżki w zespole” itd. (Oleradzka 1983).

Następnie obie artystki zrealizowały Pchtę Eugeniusza Zamiatina, gdzie wykreowały znowu „cały” teatr. Poszły tropami rosyjskiego powiedzenia o znamionach przysłowia, że „Anglicy stalową pchłę zrobili, a mieszkańcy Tuły ją podkuli i z powrotem odesłali”, w nawiązaniu do którego XIX-wieczny pisarz Mikołaj Leskow napisał opowiadanie, a Zamiatin zaadaptował je dla potrzeb Drugiego Studia Moskiewskiego Teatru Artystycznego - teatru młodych pod kierunkiem Jewgienija Wachtangowa, którzy - w opozycji do „właściwego” MChAT-u i rozwijanego w nim przez Konstantego Stanisławskiego naturalistycznego stylu inscenizacji - pragnęli wydobyć na scenie „czystą” teatralność. Przedstawienie toruńskie zaczęło się już u wejścia do starego pruskiego fortu, gdzie ukostiumowani aktorzy występowali $\mathrm{w}$ roli handlujących, następnie w szatni odbierali od widzów okrycia, a „właściwą" akcję prezentowali na długim pomoście w hali fortecznej, publiczność mając po obu stronach. Inscenizatorskie konwencje „naiwnego” rosyjskiego teatru ludowego uzupełnity z jednej strony o elementy polskiej tradycji widowisk herodowych (Diabel, Anioł i Śmierć na oczach widzów przemieniają się w osoby dramatu), z drugiej sięgają po pomysły w stylu kabaretu i teatru absurdu. Inwencja i dowcip reżyserki oraz scenografki w budowaniu świata teatralnego stają się wartością samą w sobie: całe widowisko sytuuje się między groteską i parodią, gdzie pierwsza $\mathrm{z}$ tych konwencji jest zagwarantowana dla pokazywania strony rosyjskiej, druga - Zachodu. Aktorzy są wodzirejami, popisują się gagami, idą w zawody z błaznami i klaunami, do nich się upodabniając, grają na różnych instrumentach muzycznych. Prawdziwe święto teatru w jego nurcie ludycznym.

Dwa rozwinięcia tematu. Pierwszy raz Meissner i Semenowicz „czystej” teatralności szukały nie tylko po rosyjskiej stronie. Przygotowały przedstawienie Stuga dwóch panów Carla Goldoniego (1986), które stało się popisową demonstracją zasad włoskiej commedii dell'arte, konwencji, w której aktor w roli tytułowej (Andrzej Gałła) i inni aktorzy w zakresie ruchu scenicznego ocierali się wręcz o akrobatykę. Co też godne podkreślenia: występowali 
oni (wyłączając parę kochanków) w skórzanych półmaskach rzadko spotykanych w polskim teatrze. W repertuarze teatru znalazła się potem jeszcze druga komedia Goldoniego Awantura w Chioggi w reżyserii Wiesława Komasy (1995); aktorzy w przedstawieniu nie mieli już masek.

Wracając do repertuaru rosyjskiego: Krystyna Meissner i Aleksandra Semenowicz wystawiły nie tylko niegrane w Polsce, zapoznane też w Rosji ze względów politycznych, pozycje repertuarowe. Przymierzyły się również do „klasycznego” Rewizora Mikołaja Gogola (1992). A swoistym apogeum w obcowaniu przez nie $\mathrm{z}$ dramatem i teatrem rosyjskim stała się inscenizacja Zmierzchu Izaaka Babla (1987), idąca już nie w stronę farsy, ale wręcz przeciwnie: tytuł wcześniejszego przedstawienia Teatr to świątynia wybrzmi tym samym nieironicznie.

Akcja sceniczna jest osnuta wokół dramatu rodzinnego, wyrastającego z konfliktu pokoleń. Tło stanowi bogato zarysowany obraz środowiska rosyjskich Żydów z początku XX wieku, mieszkańców Odessy. Zwięzly i dosadny język dialogów świetnie naśladuje mowę potoczną, a reszty dopełniają didaskalia, zorientowane na jak najpełniejsze projektowanie rzeczywistości scenicznej, takiej „jak w życiu”. Dzieło odwołuje się do estetyki naturalizmu i byłoby jak najdalszym od wszystkiego, co „poetyckie”, gdyby nie kilka „drobnych” szczegółów. Akcja rozgrywa się w roku 1913 - bezpośrednio poprzedzającym czas rozpadu porządku ówczesnego świata politycznego, społecznego, moralnego. Bohaterowie wywodzą się ze środowiska Żydów, których los już od wieków był „skrajnym, a więc najbardziej uderzającym - jak pisze Jerzy Pomianowski, tłumacz sztuki - przypadkiem wszelkiego losu ludzkiego" (Babel 1964: 22). Tytuł dramatu brzmi akurat Zmierzch, a poza tym w didaskaliach - przy całej prawie ich fotograficznej wierności - nieoczekiwanie przychodzi nam czytać o „płonących lasach zmierzchu”, a następnie o świetle wieczoru: „Sinawy mrok, ale nad mrokiem niebo jest jeszcze purpurowe, rozżarzone, pokryte ognistymi wyboinami” (ibid.: 534-535). I chodzi w obu wypadkach o obraz nieba - teatralnego nieba - nagle stającego w ogniu, gdy syn targnie się na ojca - zapominając o danym przez Boga przykazaniu „Czcij ojca swego...”.

Te drobne szczegóły czynią w istocie ze Zmierzchu rzecz o ludzkim świecie w ogóle, który - mówiąc słowami Hamleta - „wypada z wiązań”. Właśnie ten moment rozpadu tradycyjnych wartości religii i moralności zostaje uchwycony w metaforycznie traktowanym obrazie dramatycznej rzeczywistości. „Przebić się” tylko należy przez jej całą naturalistyczno-rodzajową materię. W teatrze - który jest sztuką konkretu - zadanie to nie najłatwiejsze. Tym bardziej że żydowska egzotyka, i to podwójna - bo środowiskowa i czasowa - pociąga tak dalece, iż wydać się może wartością samą w sobie. W Polsce konwencje naturalizmu i rodzajowości utworu Babla udało się przełamać jedynie tak wytrawnemu reżyserowi jak Jerzy Jarocki.

Krystyna Meissner uzupełniła tekst fragmentami Opowiadań odeskich (prezentujących nie tylko ten sam świat dzielnicy Mołdawanki, ale nawet te same postaci, co w Zmierzchu), a ponadto żydowskimi tekstami kanonicznymi. Na tej wzbogaconej odpowiednio podstawie materiałowej wykreowała wraz z Aleksandrą Semenowicz „wielki spektakl”, uderzający czysto teatralną urodą, jak i pełnym podporządkowaniem bogactwa różnorodnych środków teatralnych (także np. zapachu kadzideł) moralistycznej wymowie całości.

Scenografia prezentuje teren gry operujący jednocześnie kilkoma planami - poszczególne miejsca akcji jedynie zaznaczając, ale za sprawą niezmiernie starannie dobieranych 
szczegółów wyposażając je w elementy zarówno charakterystyczne, jak i bardzo „malownicze”. Na scenie mogą być symultanicznie rozgrywane z jednej strony obrazy składające się na całą panoramę ludzkich „typów” oraz zachowań (otwierająca spektakl swoista uwertura), a z drugiej - postawy te udaje się od razu konfrontować wciąż z ich religijnymi, w tradycji zakorzenionymi czy po prostu poetyckimi odpowiednikami i „prawzorami” (wracający m.in. w głębi obraz modlących się Żydów). Podobnym kontrapunktem grała też wspaniała muzyka Zbigniewa Karneckiego, wzbogacona dodatkowo o występy członków toruńskich chórów i uczniów szkół muzycznych. Inwencji wreszcie nie zabraknie Zygmuntowi Kamińskiemu, który opracował ruch sceniczny, tak ważny w licznych scenach zbiorowych. W części pierwszej widowiska konsekwentnie narastała ekspresja obrazu ludzkiej nędzy bohaterów, tak w sensie czysto materialnym, jak duchowym, moralnym.

W części drugiej wszystkie te treści niesie właściwie już akcja sceniczna, rozgrywana na przemian w gwałtownym ruchu i pełnym wymowy milczeniu. Największym zaś zwycięstwem inscenizatorki stało się to, że w momencie ataku syna na ojca nie musiało już niebo stanąć w płomieniach. Cały zresztą spektakl był rozgrywany prawie w mroku.

Po sukcesie na 29. Festiwalu Teatrów Polski Północnej (główna nagroda reżyserska i scenograficzna, aktorska dla Mieczysława Banasika, wyróżnienie dla Zofii Melechówny, wreszcie nagroda dziennikarzy dla inscenizatorek i autora muzyki Zbigniewa Karneckiego), w warszawskim Teatrze Powszechnym za dyrekcji Zygmunta Hübnera powstała druga wersja Zmierzchu w wykonaniu Krystyny Meissner. Fakt ten pozwala uznać ową inscenizację za najwyższe jej dokonanie twórcze w czasie dyrekcji toruńskiej.

\section{Teatr młodych}

Krystyna Meissner jako dyrektor nie mogła liczyć na obecność tzw. dużych nazwisk w toruńskim teatrze. Jak to wprost powiedziała w 1995 roku: „Bo choć Toruń z roku na rok się staje coraz to bardziej znaczącym środowiskiem teatralnym, to jednak ani Lupa, ani Jarocki, ani Kutz tutaj nie przyjadą. Są związani z większymi ośrodkami i po prostu Toruń nie jest im po drodze" (Meissner 1995: 11). W tej sytuacji postawiła na młodych reżyserów, udostępniając im scenę do startu artystycznego. Deklarowała wprost: „Nie zamierzam ich krępować, hamować wyobraźnię. Byle powstało widowisko atrakcyjne, kolorowe, sensowne, gdzie przede wszystkim dużo się dzieje” (Meissner 1983).

Zaprosiła do dwóch spektakli Jerzego Hutka, z którym już współpracowała w teatrze zielonogórskim. Wyreżyserował on tutaj adaptację powieści Daniela Keyesa Kwiaty dla myszy (1985) oraz dramat Wasilija Szukszyna Gdy obudza się rankiem (1985). Po telewizyjnym sukcesie Pokojówek Jeana Geneta, zaproszony do Torunia Jacek Zembrzuski przygotował Muchy Jeana Paula Sartre’a (1987), które wystawił w podziemiach Ratusza Staromiejskiego. Aleksandra Domańska z taką brawurą rozegrała w wielokondygnacyjnej i mrocznej scenerii Starych Stajni przy ulicy Reja (dziś już nieistniejących) przedstawienie Strach i nędza III Rzeszy, iż przyniosło jej ono jedną z nagród na 26. Festiwalu Teatrów Polski Północnej (1984). Krzysztof Kelm, zaczynający jako scenograf, w roli reżysera zajął się adaptacją Kobiety z wydm Abe Kobo, którą wystawił w wysypanej morskim piaskiem sali Dworu Artusa (1985). Akcja przebiegała w zwolnionym, somnambulicznym wręcz 
rytmie, co tłumaczyło się osobliwością zdarzeń (a właściwie ich braku) w japońskiej powieści. Ale ten sam rytm, bodajże bardziej jeszcze spowolniony, narzucony został przez Kelma akcji Trzech sióstr Antoniego Czechowa (1987); na scenie Teatru Horzycy został w ten sposób powołany obraz „sennego królestwa śmierci” (mówiąc słowami T. S. Eliota z poematu Próżni ludzie), napiętnowany ludzką niemocą, pustką i przemijaniem, za punkt wyjścia mający m.in. misteria Maurycego Maeterlincka, w których człowiek zostaje postawiony wobec Tajemnicy i Losu. Tak dalece uderzyło to w realistyczne z gruntu podstawy dramatu, że spektakl przez widzów został odrzucony. Ale z perspektywy lat patrząc, była to bez wątpienia interesująca propozycja wykreowania teatru metafizycznego o niezmiernie sugestywnym wyrazie plastycznym - poczynając od aranżacji otwartej przestrzeni sceny, aż po tylną zewnętrzną ścianę budynku teatralnego, z rozwartą w końcu bramą wjazdową.

Eksponując młodych reżyserów, Krystyna Meissner ryzykowała, ale i nie brakowało jej poczucia odpowiedzialności. Jak zwierzała się: „Okazuje się czasem, że zamówione u kogoś przedstawienie nie jest doskonałe od strony rzemieślniczej, że się rozpada, że nie ma rytmu, ma źle ustawione role czy inne niezdarności - kierownik artystyczny musi wkroczyć i pomóc. Jest to konieczne, [... ] jednak czuję się (wtedy) jak intruz, bo przecież wdzieram się w materię sztuki, w cudzy proces tworzenia” (Meissner 1984). Grzegorz Stanisławiak zawiódł nie tylko Wyspą róż Mrożka, ale też realizacją aktorskiego, „kobiecego” z założenia spektaklu Dom Bernardy Alba Federica Garcii Lorki (1990). Ale już Waldemar Śmigasiewicz w adaptacji Ferdydurke Witolda Gombrowicza „czysto” wyłożył zawarte w niej podstawowe autorskie założenia filozofii Formy (1984). Andrzej Markowicz, na początku scenograf, po ukończeniu reżyserii uchodził wręcz za specjalistę od Witkacego, w Toruniu w Roku Witkiewiczowskim przygotował Kurkę wodna (1985). Adaptację dwu dramatów Franka Wedekinda, Duch ziemi i Puszka Pandory zatytułowaną Lulu (1987), z popisową rolą Jolanty Olszewskiej, wystawił Michał Kwieciński. Na przykładzie dziejów głównej bohaterki „pięknego, dzikiego zwierzęcia” wykreował zupełnie nową rzeczywistość. Odrywa się ona od naturalistycznej obserwacji i modernistycznej idei metafizyki płci i idzie w stronę groteskowego zrównania świata z cyrkową areną, na której przewodzi Pogromca. W jego władaniu są nie tylko oswojone zwierzęta, ale i Lulu, daleka od ucieleśnienia Goetheańskiego ideału „wiecznej kobiecości”. Groteska święciła triumfy także w wyreżyserowanym przez Eugeniusza Korina Mandacie Mikołaja Erdmana (1988). Ta satyra na rewolucyjne społeczeństwo radzieckie, z akcją zamkniętą w klasyczne schematy farsy (perypetie wokół ożenku młodej pary, tajemniczy kufer zmieniający wciąż właścicieli, karnawałowy wątek „z chłopa król”, rozmaite qui pro quo), pozycja bestsellerowa w słynnym rewolucyjnym teatrze Wsiewołoda Meyerholda, doczekała się w Toruniu, w wykonaniu Rosjanina, wcześniej już działającego w Polsce, przedstawienia skonstruowanego z iście zegarmistrzowską precyzją i budzącego gromki śmiech w połączeniu z wielkim strachem; na czoło zespołu aktorskiego wysunęła się Jadwiga Kuta. Z kolei Moliera Mieszczanina szlachcicem, z „baletową komedią” w środku, zrealizował dobrze zapowiadający się reżyser francuski Ives Goulais (1991).

$\mathrm{Z}$ repertuaru francuskiego zostały przedstawione jeszcze dwa dramaty Alfreda de Musseta. Pierwszy to romantyczna komedia Nie igra się z miłościa w reżyserii Marka Fiedora (1994), ze Sławomirem Maciejewskim w roli głównej, drugi - dramat romantyczny Lorenzaccio w reżyserii Marcela Kochańczyka (1986), wcześniej laureata FTPP. Zainscenizował on kolejne dzieje „syna zemsty”, podobne do losów naszych Wallenrodów, Konradów, Kordianów, Wacławów, Irydionów. Nie akcentował jednak dostatecznie ob- 
razu zła, któremu podlega nie tylko Lorenzaccio (Michał Marek Ubysz), ale również ci wszyscy, w imię których dokonuje on targnięcia się na życie tyrana. Wtedy powstałaby ciekawa kontrpropozycja dla polskich dzieł romantycznych, a wielkie widowisko ze scenografią Krzysztofa Pankiewicza obroniłoby się skutecznie przed koturnowością opery. Jubileusz stulecia Młodej Polski, przypadający w 1996 roku, teatr uczcił Klątwą Stanisława Wyspiańskiego w reżyserii i scenografii debiutującego Tomasza Kowalskiego oraz Karykaturami Jana Augusta Kisielewskiego w reżyserii Iwony Kempy, która wkrótce zostanie dyrektorem artystycznym Teatru im. Wilama Horzycy.

Młodzi „atakowali” przeważnie wysoki repertuar, dysponowali interesującymi, odwołującymi się bezpośrednio do wrażliwości współczesnych odbiorców pomysłami na jego teatralizację. Jeżeli coś im się nie udawało, to najczęściej z powodu braku rzemiosła i doświadczenia w pracy z aktorami. Wyjątkiem okazał się Piotr Cieplak. Debiutował w Toruniu jako reżyser „niskich” fars - najtrudniejszej bodajże formy w teatrze. I z ogromną konsekwencją oraz kulturą wpisał akcję dwóch jednoaktówek Aleksandra Fredry Pierwsza lepsza oraz Jestem zabójca (1986) w przestrzeń górnego foyer teatru, włącznie z wielkim oknem, do którego po frontowej (zewnętrznej) ścianie budynku wdrapywał się jeden z bohaterów (scenografia Marka Brauna). To kameralne przedstawienie miało tę samą lekkość, wdzięk i dynamikę, co późniejsza inscenizacja wodewilu Żotnierz królowej Madagaskaru, gdzie Piotr Cieplak objawił z kolei umiejętność skutecznego panowania nad „rozkręconą” przez siebie machiną wielkiego widowiska i z dużą kulturą poprowadził Włodzimierza Maciudzińskiego i Bożenę Borowską w rolach głównych. Potem wziął na warsztat dwie jednoaktówki Antoniego Czechowa w spektaklu Tragik mimo woli (1991), granym znowu $\mathrm{w}$ foyer na drugim piętrze, $\mathrm{z}$ widokiem tym razem $\mathrm{z}$ góry na widownię teatru. Co najciekawsze, zaczął już przygotowywać z toruńskimi aktorami inscenizację Historyi o chwalebnym Zmartwychwstaniu Pańskim Mikołaja z Wilkowiecka. Spektakl ten, zrealizowany ostatecznie w Teatrze Współczesnym we Wrocławiu, zadziwił połączeniem scenariusza XVI-wiecznego, „prymitywnego” misterium rezurekcyjnego $\mathrm{z}$ rozwiązaniami rodem $\mathrm{z}$ teatru Mirona Białoszewskiego oraz studenckiego teatru lat 70. - i przyniósł mu już wówczas miano jednego z najwybitniejszych reżyserów współczesnego polskiego teatru po transformacji; został on zaliczony do pokolenia tzw. młodszych zdolniejszych.

$\mathrm{Na}$ czele tej generacji reżyserskiej znajduje się dziś Krzysztof Warlikowski, który w Toruniu miał z kolei swój debiut Szekspirowski. Jego inscenizacja Kupca weneckiego ze scenografią Małgorzaty Szczęśniak (1994) została prawie całkowicie przez widzów odrzucona. Ale nie było wtedy czemu się dziwić. W spektaklu zaczęły już dochodzić do głosu te wszystkie elementy, które złożą się na nową zupełnie estetykę tzw. teatru postdramatycznego: dekonstruowanie utworu dramatycznego, rozluźnienie linearnej logiki fabuły, montowanie scen na zasadach obrazów filmowych, z których mają być czerpane nie intelektualne, ale emocjonalne i zmysłowe doznania; obnażanie teatru na scenie, nieukrywającego swojej iluzyjności i sztuczności, myślenie ciałem aktora jako „zbieraczem wrażeń”; w miejsce interpretowania tekstów - używanie go do własnych celów. 


\section{Sztuka inscenizacji}

Zapytana o sposób rozumienia twórczości reżyserskiej Krystyna Meissner odpowiedziała: „Wydaje mi się, że najcenniejsze i najważniejsze w przekazie teatralnym jest to, czy uda się stworzyć pewne wydarzenie teatralne, pewną kreację teatralną organicznie związaną z tekstem" (Meissner 1994b: 5). Pomijając tryb warunkowy, w jakim jest sformułowana ta wypowiedź, najbardziej wyrazisty przykład takiego właśnie sposobu powoływania przez Meissner spektaklu teatralnego stanowi jej toruńska inscenizacja Balladyny Juliusza Słowackiego z roku 1984. Tak się zarazem dobrze składa, że obok znajomości przedstawienia z autopsji i recenzji mogę przywołać jeszcze zapisy wybranych prób w trakcie pracy nad nim (Stuczyńska 1985).

Stosunkowo krótko przed toruńską inscenizacją w polskich teatrach pojawily się trzy znaczące realizacje tego dramatu. Pierwsze: głośna, przez lata grania w Teatrze Narodowym (1974) inscenizacja Adama Hanuszkiewicza z hondami na scenie, w której utwór był inscenizowany „od końca”, tj. z punktu widzenia Epilogu i zawartych w nim w stopniu najpetniejszym zabiegów dystansujących. Drugie: wystawiane w krakowskim Teatrze „Bagatela” przedstawienie Mieczysława Górkiewicza ze scenografią i kostiumami Tadeusza Kantora (1974), w którym akcja toczyła się w świecie półumarłym, gdzie trudno rozdzielić żywych ludzi od manekinów. Trzecie: spektakl Janusza Wiśniewskiego w Teatrze Nowym w Poznaniu (1979), inspirowany doświadczeniami współczesnego malarstwa, kina i komiksu, z wykreowanymi na scenie postaciami Strachu, Śmierci, Szatana, Anioła itd. Już te trzy realizacje dowodziły m.in., nie mówiąc już o wcześniejszych premierach Balladyny (poczynając od prapremiery we Lwowie w 1862 roku) - szczególnej złożoności dramatu Słowackiego, który w teatrze - jak określiła to Marta Fik - „jakoś dziwnie nie chciał się złożyć w całość przekonującą, tkwiące w utworze sprzeczności, w lekturze świadczące o zapożyczeniach, ale i oryginalnej poetyce, na scenie rozpadały się na poszczególne wątki na ogół mało spójne" (Fik 1989: 338). A poza tym istnieje jeszcze inny problem. Jak pisał Edward Csató:

Utwory takie jak Balladyna są nam w pewnym sensie znane z góry, choćbyśmy ich jeszcze nie czytali - ponieważ owe wątki i ów arsenal, jakim operuje Słowacki, bardzo się z biegiem lat spopularyzowały. [...] Jeśli więc dzisiaj pragniemy zasugerować publiczności ową rzeczywistą oryginalność jego dramatu musimy przedstawienie skomponować w taki sposób, aby miało ono dla widza coś nieznanego i niezwykłego (Csató 1960: 105).

Krystyna Meissner była świadoma obu tych uwarunkowań. W natłoku literackich znaczeń, tak licznych, że w teatrze nie może na nie wszystkie naraz odpowiedzieć, a zarazem dążąc do uzyskania „niezwykłości” swojej propozycji scenicznej, inscenizatorka postawiła na kompozycję i formę spektaklu. Jak powiedziała na wstępie prób analitycznych do zespołu: „Ważna jest realizacja anegdoty, a nie anegdota”. To powoduje, że do teatralnego scenariusza przedstawienia wprowadziła pełny tekst ballady Maliny Aleksandra Chodźki, ponadto przejętą ze zbiorów Oskara Kolberga balladę Pani pana zabiła (którą Mickiewicz wykorzystał w słynnej balladzie Lilie, a której inspiracje są również widoczne w dramacie) oraz fragment z Rapsodu III Króla-Ducha: 
A teraz powiem, jak antychrystowe

Moce w Słowiaństwie wstały - jaka była

Niewiasta, która przeciwbożną głowę

Wzniosła - i za cel piorunom stawiła.

Ta odtąd stoi duchom za królową

I na świat - swoje służalce posyła ${ }^{1}$

Te trzy dodatkowe teksty przyporządkowała Meissner postaci konstruowanej jako Chór-gmin, który nie istnieje - nie na taką w każdym razie skalę - w dramacie, daje się jednak z niego wyprowadzić. I to nie tylko ze sceny przyglądania się przez „wieśniaczy lud” pogorzelisku po chacie Wdowy (akt trzeci, scena pierwsza), czy też z jawnie łamiącego teatralną iluzję Epilogu, w którym do głosu zostaje dopuszczona Publiczność oglądająca w teatrze historię Balladyny. Ponadto postać zbiorowa Chóru-gminu przynależy do „głębokiej” tradycji dramaturgiczno-teatralnej tragedii greckiej, która akurat właśnie w okresie przedi romantycznym była na nowo rozpoznana przez Niemców. Zdaniem Friedricha Schillera chór pełnił w dziełach tragików greckich rolę swoistej granicy, „muru żywego”, oddzielającego idealny świat tragedii od konkretnej rzeczywistości historycznej, zarazem służył wydobywaniu na scenie gry między iluzją i deziluzją. Z kolei według słynnej formuły Augusta W. Schlegla chór to idealny widz, właśnie Publiczność w Epilogu Balladyny.

Krystyna Meissner na próbach teatralnych podkreślała, że Chór komentuje zdarzenia z planu głównego akcji, ale i w pewnym sensie je tworzy. Chór porównuje z jednej strony do postaci z obrazu Hieronima Boscha Statek szaleńców, z drugiej ich zachowania na scenie zestawia z postawami obserwatorów z opowiadania Kraksa Dürrenmatta. Stosunek Chóru do Filona, który jest świadkiem brutalnej prawdy o śmierci Aliny, swej ukochanej, a jednocześnie stanowi przedmiot drwin Chóru jako postać śmieszna. Z tego stosunku Gminu do Filona bierze się - zdaniem Meissner - cała forma sceniczna Balladyny. W trakcie prób poszukuje sposobów zindywidualizowania Chóru, od strony psychologicznej: tworzą go fanatycy sprawy, histeryczne kobiety, prowokatorka; od strony fizycznej: chroma dziewczyna; od strony profesjonalnej: wszyscy to angażujący się w przedstawienie amatorzy, ale i ujawniający też swoją prywatną postawę wobec wydarzeń przedstawienia. Istnieje konflikt między Chórem a postaciami z Balladyny; do jakiego stopnia się ten rozwinie, na początku prób Meissner nie miała pewności, stawiając aktorom zadanie obrony swoich postaci do samego końca.

Jednocześnie Chór ma mieć udział w budowaniu napięcia na linii scena-widownia. W odniesieniu z kolei do bohaterów akcji Meissner dba cały czas o utrzymanie balladowej formy całości, zgodnie z tekstem listu do matki, gdzie Słowacki pisał: „tragedia cała podobna do starej ballady, ułożona tak, jakby ją gmin układał” (Słowacki 1962: 273). Jednocześnie pilnuje na próbach, aby aktorzy nie ewokowali świata Szekspira: bo i w tę stronę kieruje autokomentarz poety: „Jeżeli ma (ta tragedia) rodzinne podobieństwo z którą znajomą sztuką, to chyba z Królem Learem” (ibid.).

Pora przejść do samego spektaklu. Włączony do scenariusza cytat z historiozoficznej epopei Słowackiego Król-Duch anonsuje przedstawione w utworze dzieje Pychy, żony Piasta - w stosunku do tragedii o Balladynie rozwijając się w innym porządku fabularnym

1 Dokładnie: z odmian tekstu początku rapsodu III; Słowacki 1952: t. V, 278. 
i służąc innemu przesłaniu ideowemu. Ale w ogólnym wydźwięku mogą one zapowiadać historię tytułowej bohaterki tragedii z czasów także „bajecznych” i o aspiracjach również historiozoficznych: „przciwbożnej niewiasty”, która zginęła od „pioruna” - i ciąży odtąd (w zgodzie z historiozoficzną właśnie lekturą Balladyny) nad dziejami Polski. W stosunku do tragediowego oryginału - przynależącego do grupy dramatów tzw. ironicznych - przydają mu tylko wyraźniejszą perspektywę metafizyczną oraz narodową: w zgodzie z kolei z poetyką i problematyką twórczości okresu tzw. mistycznego, z którego pochodzi KrólDuch. Ta zaś perspektywa pozostaje już w dużym stopniu zgodna ze świadomością religijną oraz narodową wiejskiej gromady, która w spektaklu Meissner przedstawia widzom historię Balladyny, z „chłopianki” królowej.

Mickiewicza Lilie oraz Maliny Chodźki stanęły u początku całej wczesnoromantycznej balladomanii, odpowiedzią na którą to ze strony Słowackiego była właśnie Balladyna - swoista hiperballada, w której tworzeniu powagę wiązał on z dystansem i zabawą. W dramacie na czoło wysuwa się w rezultacie jego autorskie, podmiotowe „ja”, w suwerennym akcie kreatorskim powołujące poezję z poezji (oprócz ballad romantycznych - ponadto wyrastająca jeszcze z komedii, tragedii i kronik dramatycznych Szekspira). Ale u głębszych podstaw kształt dramatu Słowackiego dopuszcza oddanie głosu ludowemu podmiotowi zbiorowemu, który swoją twórczością inspirował romantycznych poetów. Ten właśnie ludowy podmiot zbiorowy znalazł w rękach Krystyny Meissner reprezentację na scenie toruńskiej. Nie tylko jednak jako wykonawca ludowo-romantycznych ballad. I bynajmniej nie w postaci jakiejś grupy historycznej.

Za sprawą Aleksandry Semenowicz jako autorki scenografii na scenie znalazł się blisko dwudziestometrowy podest $\mathrm{z}$ jasnego, czystego drewna, podniesiony i biegnący do jej wnętrza, obniżający się zarazem ukośnie ku pierwszym rzędom widowni, wyłaniający się z ciemności. Na nim są prawdziwe belki kolejowe przywołujące wyglądem ściany chałupy wiejskiej oraz zwisająca z góry lina, oddana do dyspozycji (jak flugi w romantycznym teatrze) głównie postaciom $\mathrm{z}$ planu fantastycznego. Na tę scenę pełną powietrza wkraczali mężczyźni i kobiety ubrani współcześnie. Ich stroje były odświętne, jednocześnie przez ramię mieli przerzucone fragmenty kostiumów bądź też prześwitywały im one przez ubrania; resztę potrzebnych do gry elementów będą wydobywać z walizek, teczek i toreb podróżnych, które trzymają w rękach; to swoista amatorska trupa teatralna. Historię o Balladynie znają na pamięć, mimo to w trakcie jej odgrywania uważnie obserwują toczące się wydarzenia - cały czas niemal obecni na scenie, włączają się ponadto w ich przebieg - słowem czy gestem (gdy zabrakło już stosownego tekstu Słowackiego), doradzając bohaterom, przestrzegając ich przed konsekwencjami ich uczynków itd. Dotyczy to przede wszystkim poczynań Balladyny: przed zbrodnią rzucają jej nóż pod nogi, gdy została królową - składają hołd, a na końcu zdają się ją osaczać; odstępują dopiero wtedy, gdy ona - sama wydawszy na siebie wyrok - ginie. Przepada w rezultacie stopniowo radość grania, której dawali wyraz na początku - podobni w tym postępowaniu do rzemieślników z Szekspirowskiego Snu nocy letniej, inscenizujących historię Pyrama i Tyzbe, na rzecz coraz głębszego angażowania się $\mathrm{w}$ tworzone przez siebie przedstawienie - jakby tym widowiskiem mogli naprawić świat, co w tym wypadku znaczy: przestrzec Polaków przed oddziaływaniem „przeciwbożnej niewiasty”, której „służalce” rozpętują „moce antychrystowe”.

Powołanie w przedstawieniu Krystyny Meissner Chóru-gminu wprowadzało do niego płaszczyznę „teatru w teatrze”, nadawało mu charakter „ballady o Balladynie” - jak na 
próbach określiła to reżyserka, przede wszystkim jednak został w ten sposób stworzony element zapośredniczający, wyobcowujący całą rzeczywistość - tak, aby mogła ona uzyskać dodatkowe sensy narodowe, szczególnie aktualne krótko po zawieszeniu w Polsce stanu wojennego, kiedy to odbyła się premiera spektaklu. Zainscenizowana przez wiejską gromadę historia Balladyny jawiła się ostatecznie jako exemplum toczącej się ustawicznie w dziejach Polski walki Dobra i Zła, demonstrowała zarazem destrukcyjne oddziaływanie bezprawia na ludzką zbiorowość, naród. Bezprawia, które - jak mówił w części pierwszej przedstawienia Kirkor - „gorzej od Mojżesza plagi kala tę ziemię”, która - jak wtórował mu Chór, śpiewający do pięknej muzyki Zbigniewa Karneckiego - „upałem wysuszona pęka, / / Ta sama Polska, niegdyś tak obfita, staje się co rok szarańczy spichlerzem...” (Słowacki 1952: t. VII, 14-15). Przesłanie to w zamierzeniu inscenizatorki było tym bardziej znaczące, skoro tą samą pieśnią miało wybrzmieć na końcu całe przedstawienie. Tyle że na taki jego finał nie zezwoliła cenzura.

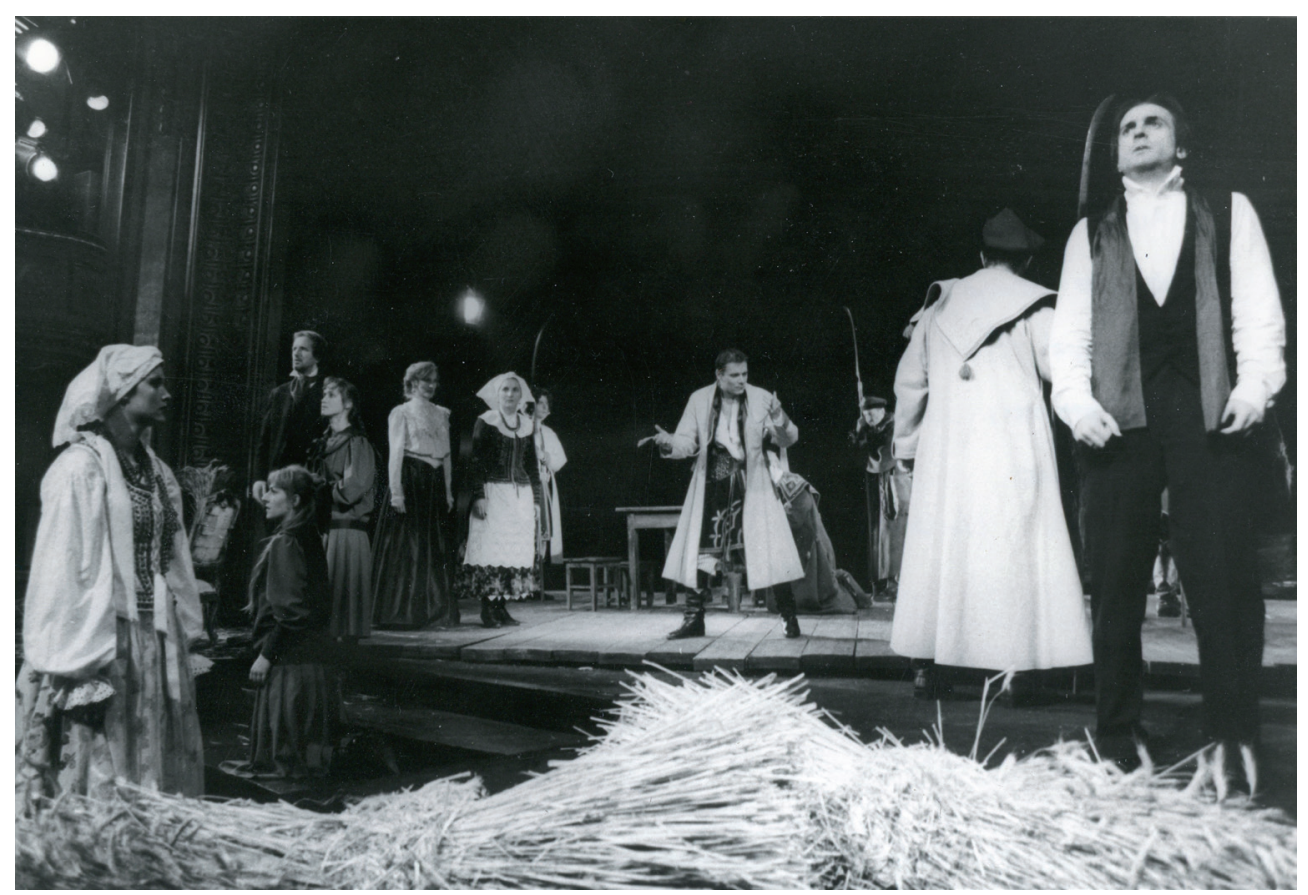

Wesele S. Wyspiańskiego w reż. Krystyny Meissner (scena zbiorowa)

Fot. Stanisław Wojciech Reszkiewicz. Z archiwum Teatru im. W. Horzycy

Krystyna Meissner jako inscenizatorka Balladyny głęboko pochyla się nad dramatem Słowackiego, by dotrzeć do jego kompozycji, formy, struktury. Idąc tą drogą, w scenariuszu reżyserskim odpowiednio go modeluje i dociera do zawartego w nim depozytu znaczeń. W tych ramach konstruuje całościowe przesłanie spektaklu, dostosowane do tu i teraz. $\mathrm{Z}$ dwu możliwości twórczego opanowania materii literackiej skupia się przy tym nie na postaciach, lecz na akcji dramatycznej, wydobywając sceniczną atrakcyjność anegdoty, walory 
widowiskowe działań bohaterów. Słowo wspiera cały czas obrazem, ruchem. Wypełniając zaprojektowaną przez Aleksandrę Semenowicz prawie pustą przestrzeń sceny z minimum przedmiotów, wyabstrahowaną prawie z realności pozascenicznej, kreuje rzeczywistość z gruntu teatralną, antyiluzjonistyczną, w której prawdy życia łączy z demonstracją teatralnej umowności, piętrzeniem iluzji na prawach „teatru w teatrze”. Całości dopełnia, nie jako ilustracja czy tło, ale w funkcji ekspresyjnej muzyka Zbigniewa Karneckiego. Tak powstaje teatralny teatr Krystyny Meissner, dochodzący do głosu - z różną intensywnością - także w innych jej przedstawieniach.

\section{Teatralne wieczory polskie}

Tak Krystyna Meissner nazwała spektakl, w którym Nie-Boską komedię Zygmunta Krasińskiego połączyła $\mathrm{z}$ adaptacją teatralną powieści Tadeusza Konwickiego Mała Apokalipsa, a kształt scenograficzny przedstawienia oddała znowu w ręce Aleksandry Semenowicz. Wspólny w tych utworach wątek fabularny oraz ideowy odnalazła w obrazie katastrofy oraz poety, pisarza wobec historii. Zderzenie obu utworów podczas jednego wieczoru teatralnego dawało pełną ekspresji wizję dwu etapów w rozwoju dziejów: sprzed oraz po rewolucji. Ekspresję tę określało w pierwszym rzędzie rozegranie przedstawienia w obrębie całego niemal gmachu toruńskiego teatru. Jego część pierwsza, tj. Nie-Boska komedia rozgrywa się w rozświetlonej przestrzeni pustej widowni, z widocznymi ze sceny (skąd widzowie oglądali spektakl) pięknymi, stylowymi balkonami i lożami, na uniesionych ponad fotelami podestach ułożonych w kształcie skośnego krzyża. Zaś w części drugiej, Mała Apokalipsa - na scenie zamkniętej żelazną kurtyną, z odsłoniętymi z kolei widocznymi w mroku ścianami „roboczego” zaplecza i prezentującymi przestrzeń baru mlecznego ze stolikami, między którymi widzowie siedzieli na specjalnie przygotowanych ławach. Już w tym kontekście świat Konwickiego jawił się jako tym bardziej jeszcze zdegradowany, natomiast świat Krasińskiego vice versa: ulegał podniesieniu, wyestetyzowaniu. Reszty efektu dopełniły odpowiednio dobrane kostiumy aktorów, rekwizyty i sprzęty uruchamiane w toku akcji teatralnej: również diametralnie różniące się w wymowie ideowej oraz wydźwięku estetycznym. Wszystko to jednak „pracowało” na „apokaliptyczność” rzeczywistości Małej Apokalipsy: zawartego w niej obrazu świata „zdruzgotanego” i narodu, który „wyparowuje w nicość” (Konwicki 1991: 8). Dla próby interpretowania Nie-Boskiej komedii w duchu narodowym (w zgodzie z tytułem całego spektaklu Wieczór polski), dla głębszego w ogóle interpretowania dramatu Krasińskiego - poza wydobyciem z niego „pięknego teatru” - zabrakło już właściwie miejsca. Końcowy zaś powrót w przedstawieniu - po podniesieniu żelaznej kurtyny - do scenerii rozegranej wcześniej Nie-Boskiej komedii akcentował dodatkowo teatralność także rzeczywistości powołanej przez Konwickiego.

„Wieczorem polskim” staje się również inscenizacja „arcypolskiej” komedii Aleksandra Fredry Zemsta, przygotowana przez Meissner i Semenowicz na inaugurację kameralnej Sceny na Zapleczu (1994). Cała komedia (w końcu ironiczna) zostaje zderzona ironicznie z całym prawie romantycznym sztafażem polskości: płaczącą wierzbą, graną na pianinie muzyką Chopina i tańczonym w rytm poloneza finałem, odwołującym się do Mickiewiczowskiego „Kochajmy się”. Jednocześnie w ściśle teatralnym, tj. umownym an- 
turażu (z dużymi polnymi kamieniami markującymi mur graniczny, o który idzie tu spór) stara wierzba jest jak najbardziej „żywa” i co rusz w jej gałęziach przychodzi się plątać aktorom, wysokie „C" Chopinowskiej muzyki pobrzmiewa dysonansem wobec prawno-matrymonialnej akcji, a końcowy polonez staje się odwróconą repliką chocholego tańca z Wesela (z którego Meissner zrezygnuje potem w inscenizacji tego dramatu) (Skuczyński 1994: $7-8)$.

Już Balladyna, następnie te dwa „wieczory polskie” odnosiły się do aktualnej sytuacji społeczno-politycznej kraju w czasach przełomu, stanu wojennego i po roku 1989. Ale nie wprost. Na pytanie postawione przez dziennikarza, czy teatr powinien się jakoś ustosunkować wobec zmian w polityce, Krystyna Meissner odpowiedziała: „W żadnym wypadku do polityki, bo wydarzenia są zawsze bardziej gorące niż teatr. Tu powinno nastąpić wyciszenie, wyjście z życia codziennego w kierunku refleksji i relaksu. Nie powinno się jazgotać ze sceny wypadkami współczesnymi. Musi to być ukryte głębiej, metaforyczne, przetrawione" (Meissner 1984). W innej wypowiedzi do prasy stwierdziła: „Nie interesuje mnie polityka sensu stricto - przynajmniej na scenie. Mnie interesują skutki, jakie w człowieku wywołują działania polityczne" (Meissner 1991). A w jeszcze innym wywiadzie konstatuje: w czasie przełomu istnieje „konieczność formułowania od początku zasad moralnych”, dodając jednocześnie - teatr powinien dać widzom „odpocząć od chaosu wokół siebie”, stworzyć okazję, by „znaleźć drugiego jakby człowieka, z którym rozmowa przynosi pewien spokój i dystans" (Meissner 1994a).

Kiedy Krystyna Meissner realizowała Balladynę, to operowała utworem znanym z góry (jak pisał Edward Csató), inscenizacja dramatu Stanisława Wyspiańskiego Wesele oznacza dla reżysera konfrontację z tekstem, którym wręcz mówimy; dzieje się tak za sprawą skrzydlatych słów, co „wpadają w ucho i zatrzymują się w pamięci” (Henryk Markiewicz w antologii Skrzydlate słowa naliczył przeszło pięćdziesiąt tego rodzaju słów z Wesela - od „Co tam Panie, w polityce”, po „chocholi taniec”). W tym wypadku reżyserskie opracowanie tekstu nie polegało na znalezieniu jakiegoś pomysłu „kompozycyjnego” na przedstawienie, liczył się każdy najdrobniejszy szczegół w scenicznych rozwiązaniach danych przez autora sytuacji, dialogów, monologów - od didaskaliów poczynając.

Aleksandra Semenowicz jako scenograf spektaklu nie rekonstruowała bronowickiej izby z jej całym wyposażeniem - ze szczegółami prezentowanymi przez poetę, ale głównym miejscem akcji uczyniła długi podest z jasnych desek, idący w głąb sceny; to przestrzeń dla weselników. W centrum stoi stół - co zaskakuje - kwadratowy, z czterem prostymi, zwykłymi stołkami, zastawiony baterią flaszek wódki, pitej potem - co znowu uderza - na rosyjską modłę szklankami; w tyle pomostu postawiono dużą skrzynię, która zanim stanie się skrytką dla złotej podkowy, posłuży Isi za łóżko. Za głównym podestem znajduje się drugi, pochylony pod kątem ku widowni, gdzie są umocowane chochoły; tu będą ukazywać się Osoby dramatu. Ponadto do gry zostaje włączone proscenium, na którym po prawej stronie stoi zbroja, po lewej fotel, z leżącą na nim czapką z piór. Po obu stronach walają się snopki zboża. Ściany są czarne i jest to kolorystycznie doskonały punkt wyjścia dla przyszłej gry świateł. Jako historyczne zostają natomiast zaprojektowane kostiumy.

Na zaproponowane przez Aleksandrę Semenowicz podstawowe dla akcji Wesela przestrzenne elementy Krystyna Meissner rozpisała cały spektakl, proponując równie dyskretne, tj. antyiluzjonistyczne, uteatralizowane reżyserskie rozwiązania. Pierwszym z takich rozwiązań - porównywalnym z rolą Chóru-gminu w Balladynie - jest ramowa kompozycja 
spektaklu. Na samym jego początku - przy świście wiatru - „wszyscy aktorzy, którzy będą brać udział w przedstawieniu, wychodzą na scenę. Pewnie stąpają. Zimnym wzrokiem spoglądają przed siebie, jakby chcieli powiedzieć, że również widzowie biorą na siebie odpowiedzialność za to, co się tutaj stanie. Kiedy ta myśl znika, oni odwracają się. Zapada pólmrok" (Mendelewska 1997: 14). W toku akcji scenicznej zostaje rozbity szopkowy układ scen na rzecz zasady przypominającej bardziej montaż filmowy. Reżyserka wprowadza postaci, które w danej scenie w oryginale nie występują. Potem akt drugi łączy z trzecim. W ten sposób uzyskuje efekt ironiczny wymowy sceny, korespondujący z kolei z wcześniejszą inscenizacją Zemsty: podczas rozmowy z Haneczką Pan Młody prawi siostrze morały, a jednocześnie na kolanach siedzi mu Panna Młoda. Częściej jednak w układzie scen „uderza pewne niezgranie, tzw. prywatne zejścia aktorów lub brak zajęcia tych, którzy czekają na »swoją kolej«”. W rozmowie Pana Młodego z Gospodarzem, gdzie padają słowa „Myśmy wszystko zapomnieli”, uczestniczy też Ksiądz, którego „zachowanie jest bierne” i tylko niepotrzebnie odwraca uwagę od wagi tych (dziś jednych ze skrzydlatych) słów. Albo Gospodarz podśpiewuje - od czasu do czasu - dodaną do scenariusza spektaklu ulubioną piosenkę Włodzimierza Tetmajera Kurdesz. W scenach z Rachelą reżyserka eksponuje czerwoną chustę, którą bohaterka pozostawia w różnych miejscach na scenie; to kompozycyjne w zakresie ruchu scenicznego działanie - jak zauważa recenzentka - „niczego nie wyjaśnia i nie symbolizuje" (ibid.), tak w obrazie bohaterki, jak w zainaugurowanych przez jej wystąpienie w dialogu z Poetą swoistych „Dziadów na weselu”.

Temu wizyjnemu planowi kompozycyjnemu spektaklu Krystyny Meissner poświęca zresztą - w przeciwieństwie do scen realistycznych, w których eksponuje głównie ich stronę obyczajową - mniej uwagi. Spośród umieszczonych na tylnym podeście chochołów, z mroku jakby jesiennego ogrodu, wyłaniają się Osoby dramatu, tj. duchy polskiej historii. Z ich wystąpień zostaje wydobyta głównie tradycja rycerska (zbroja na proscenium), $\mathrm{z}$ wystąpienia Wernyhory zapowiadającego z kolei na weselu - insurekcję, powstanie narodowe - wątek ludowy (czapka z piór). Odchodząc w przedstawieniu od staranniej rekonstruowanych realiów historycznych, reżyserka nie wprowadza zarazem wyraźniejszych współczesnych odwołań. W tej sytuacji finał rozegranej akcji teatralnej może być tylko taki: „Świta - a na scenie coraz ciemniej. Krzyk Jaśka: »Pieje kur!«, którego nie słyszymy, świst wiatru, muzyka przypominająca dźwięk rogu. I znów aktorzy postępują o krok w stronę widzów, są wszyscy. Ich wzrok, który każe również nam wziąć odpowiedzialność za brak czynu. Wina ma spaść również na nas” - jak pisała recenzentka (ibid.: 15). A inny recenzent dodaje: „Dopiero finał bez chocholego tańca sprawia jednak, że robi się zimno i gorzko. Bo znów trzeba zadać sobie pytanie, czy diagnoza nie jest aktualna” (Majcherek 1997: 18). Ze sceny rozległ się apel o przystąpienie do nowego działania na rzecz kraju, Polski.

Według tradycji polskiego teatru realizacja dramatu Wyspiańskiego jest sprawdzianem kondycji zespołu aktorskiego, jakim dysponuje dana scena. Wystawiona na sam koniec dyrekcji Krystyny Meissner z okazji stulecia Młodej Polski premiera Wesela objawiła w tym zakresie pewne luki. Dla części znaczących ról trzeba było sprowadzić aktorów z innych teatrów - w tym i tych, którzy wcześniej pracowali w Toruniu.

Za dyrekcji Krystyny Meissner na scenie Horzycy grali aktorzy różnych pokoleń. Spośród pracujących od dawna byli to: Grażyna Korsakow, Zofia Melechówna, Tatiana Pawłowska, Wojciech Szostak. Od czasów Marka Okopińskiego występowali Jerzy Gliński oraz początkująca wówczas Anna Romanowicz-Kozanecka, potem dołączył z pokolenia 
starszego zaproszony przez Meissner Mieczysław Banasik. Większość zespołu tworzyli jednak aktorzy młodzi; ściągnięci z Zielonej Góry Piotr Chudziński, Niko Niakas, Jacek Opolski, a następnie Jolanta Olszewska, Mirosław Guzowski, Maciej Dahms. Potem dołączyli m.in. Michał Marek Ubysz, Jadwiga i Tadeusz Kutowie, Maria Kierzkowska, Jolanta Teska, Ryszard Balcerek, Ildefons Stachowiak, Sławomir Maciejewski, Małgorzata Abramowicz, Jarosław Felczykowski, Włodzimierz Maciudziński².

\section{Festiwal „Kontakt”}

W roku 1989 dobiegły końca dzieje Festiwalu Teatrów Polski Północnej, najstarszej tego typu imprezy w kraju, która powstała w 1959 roku z inicjatywy Hugona Morycińskiego, rozwijała się też dobrze za dyrekcji Marka Okopińskiego. Z perspektywy czasu „trudno dziś mówić, aby teatry tego regionu były [miały być - J. S.] postrzegane w jakikolwiek odrębny sposób na mapie teatralnej kraju" - pisał badacz tej wspólnoty festiwalowej (Butkiewicz 2000: 406). Natomiast Krystyna Meissner, której przyszło ogłosić likwidację festiwalu głęboko zakorzenionego już w Toruniu, tłumaczyła się wprost: FTPP rolę promocji scen z północnych województw pełnił „do czasu, dopóki nie powstały inne ogólnopolskie przeglądy, które stały się konkurencyjne wobec toruńskiego, ponieważ uczestnictwo w nich zapewniało większy prestiż, zwłaszcza jeżeli teatr otrzymywał nagrodę. Nasz [festiwal - J. S.] więc siłą rzeczy zaczął podupadać i w końcu okazał się niepotrzebny” (Meissner 1992b: 1). Swoimi przedstawieniami, zdobywającymi najwyższe laury, broniła go jednak do końca. A następnie zaproponowała ogromne przedsięwzięcie, które w roku 1991 mogło wydawać się pomysłem nie do zrealizowania.

Mówiła na łamach „Teatru”:

Zastanawialiśmy się, że mógłby to być (dalej) festiwal miast Północy, tylko szerzej rozumiany. Rozważaliśmy, czy można go otwierać kluczem Hanzy? - czyli historycznego związku kupieckiego miast europejskich, do których należały m.in. Poznań, Wrocław, Gdańsk, Toruń, Praga i oczywiście mnóstwo miast w Niemczech. Mankamentem tego klucza okazała się nikła obecność miast rosyjskich w tym związku. W końcu zdecydowaliśmy inaczej. Aktualnie istnieje potrzeba zszywania Europy, Wschodu i Zachodu (Jagodzińska, Wiśniewska 2000: 448).

Zaczęła w 1990 roku od przeglądu przedstawień litewskiego reżysera Jonasa Vaitkusa (włącznie z jego pierwszymi na Litwie Dziadami Adama Mickiewicza prezentowanymi na scenie Teatru Wielkiego w Warszawie). Od roku 1991 odbywały się kolejne edycje Międzynarodowego Festiwalu Teatralnego „Kontakt”, których efektem

powinno stać się tworzenie nowych płaszczyzn kontaktu między środowiskami artystycznymi Europy Środkowej i Wschodniej, służących zbliżaniu tych kultur w nowej, diametralnie zmienionej sytuacji politycznej i społecznej. Idea festiwalu zmierza ku przeciwdziałaniu wszelkim odmianom ksenofobii, służąc rozszerzaniu obszarów tolerancji poprzez bogactwo treści

\footnotetext{
${ }^{2}$ W tym szkicu objąłem uwagą - mniej lub bardziej dokładnie - wszystkie siedemdziesiąt sześć premier w Teatrze im. Wilama Horzycy za dyrekcji Krystyny Meissner.
} 
i formy wyrazu artystycznego, wypływających z różnych źródeł kulturowych i składających się na wielowątkowy obraz kultury naszego regionu Europy. Festiwal służy także promocji najciekawszych wydarzeń teatralnych tej części Europy i ujawnianiu jej kulturowego bogactwa (ibid.: 449).

Festiwal ściągał do Torunia najciekawsze spektakle teatralne sąsiadów ze Wschodu, z kręgów teatrów poszukujących, z pogranicza teatru tradycyjnego, i umożliwiał ich konfrontację z prezentacjami teatrów zachodnich. Program festiwalu jest autorski, co jednak nie wyklucza, że przy jego układaniu Meissner kieruje się „nie tylko moim gustem, ale też gustem publiczności” (Wiadomości Kulturalne 1994). Razem z Anną Błaszczak, kierownikiem literackim teatru, odbywają długie podróże ( w tym do Rosji) w warunkach bynajmniej nie komfortowych; wyznaje Krystyna Meissner: „Bardzo często samochodem, w którym się śpi. Jeżeli musimy korzystać z samolotów, staramy się o zrefundowanie kosztów przez instytucje, które nam pomagają. Omijamy hotele, sypiamy u znajomych, gdzie można, byle darmo albo tanio, w młodzieżowych schroniskach, we wspólnych salach" (ibid.). Docierają do takich krajów, jak Jakucja, Tadżykistan, Turkmenia, Uzbekistan, Kazachstan, ponadto Wietnam i Chiny - i teatry tych krajów wprowadzają również do programu festiwalu.

Za dyrekcji Krystyny Meissner zostali wypromowani - stając się odkryciem „Kontaktu” - głównie twórcy litewscy, rosyjscy i niemieccy. Po Jonasie Vaitkusie goszczącym też na festiwalu, a odwołującym się do dawnej kultury litewskiej, zaprosiła Rimasa Tuminasa z Teatru Małego oraz Eimuntasa Nekrošiusa z Teatru Młodzieżowego w Wilnie. Ci dwaj ostatni zachwycili w przedstawieniach swoistym realizmem metafizycznym. Dodajmy, że Nekrošius był wtedy jeszcze przed prezentacją w Toruniu głośnych spektakli Szekspirowskich Hamleta i Makbeta pod szyldem Festiwalu LIFE. Wśród twórców rosyjskich na „Kontakcie” znalazł się Piotr Fomienko ze swoim młodym zespołem Pracowni w Moskwie, podejmującym próbę wznowienia tradycji tzw. Drugiego MChAT-u, na czele którego stał Michaił Czechow; w przedstawieniu Wilki i owce Aleksandra Ostrowskiego pokazywali oni z finezją i wdziękiem, że źródła stylu „gry rosyjskiej komedii satyrycznej z XIX wieku tkwią głęboko w komedii dell’arte”. Moskiewski zespół Siergieja Arcybaszewa z Rosyjskiego Eksperymentalnego Teatru na Pokrowce przedstawił Trzy siostry Antoniego Czechowa, w akcie pierwszym czyniąc widzów gośćmi w domu Prozorowych na imieninach u Iriny (jak to widział Konstanty Stanisławski), a następnie odsuwając ich i sprowadzając do pozycji obserwatorów; aktorzy zaczynali grać w ubraniach współczesnych, stopniowo przechodząc do kostiumów z początku XX wieku. Walery Fokin wystawił w moskiewskim Centrum Sztuki im. Meyerholda adaptację Martwych dusz Mikołaja Gogola.

Widzowie umieszczeni w przestrzeni Pokoju hotelowego, w mieście N. N. [tytuł spektaklu - J. S.] oglądali (podglądali) szczegóły intymnego życia Cziczikowa nie opisane przez pisarza. Na drobiazgowy realizm tej inscenizacji (odtworzono w szczegółach tytułowy pokój w prowincjonalnym hotelu), stwarzający pełną iluzję przedstawionego świata, nakładała się fantasmagoryczna wizja nieogarniętych rosyjskich przestrzeni, uzyskana dzięki niepokojącej warstwie dźwiękowej, docierającej z zewnątrz, z daleka (Osińska 2000: 492-493).

Prezentujące się na festiwalu za dyrekcji Krystyny Meissner zespoły niemieckie, mające wtedy wielki wpływ na estetykę polskich „młodszych zdolniejszych”, to m.in. Residenttheater z Monachium z przedstawieniem Śmierć Natana według dramatu Gottholda 
E. Lessinga w reżyserii Georga Taboriego, Deutsches Schauspielhaus z Hamburga ze spektaklem Chmury. Dom rodzinny według tekstu Elfriede Jelinek, wreszcie Volksbühne am Rosa-Luxemburg-Platz z Berlina z Murx den Europäer. Wieczór patriotyczny (Załatw Europejczyka) w reżyserii Christopha Marthalera. Drugie przedstawienie to rozpisana na głosy sześciu kobiet, zamkniętych w przestrzeni betonowego bunkra wśród wojennych rekwizytów, spowiedź duszy niemieckiej. Trzecie zaś - wieczór piosenek, obraz tego, co dokonało się w krajach postkomunistycznych, z NRD na czele. Z myślą o szerszej publiczności wychodzącej poza fachowców i krytyków teatralnych Krystyna Meissner zapraszała z Polski i z zagranicy widowiska plenerowe i uliczne, które na czas trwania „Kontaktu” przemieniały Toruń w miejsce autentycznego święta teatru.

Nie udał się tylko drugi, wychodzący znowu daleko poza Toruń, na cały kraj zamysł dyrektorki Teatru Horzycy: stworzenia muzeum scenografii. W Nowym Arsenale podczas festiwalu zorganizowała już wystawę prac scenograficznych, prowadziła rozmowy w sprawie włączenia do tej inicjatywy władz miejskich i kościelnych Chełmna.

Krytyk Andrzej Hausbrandt powiedział kiedyś, że Krystyna Meissner jest jedynym prawdziwym mężczyzną wśród polskich dyrektorów teatrów. Realizacji tego pomysłu na muzeum stanęły na przeszkodzie jej inne plany zawodowe. Stworzenie przez Krystynę Meissner festiwalu „Kontakt”, konsekwentne jego rozwijanie w kierunku coraz to bardziej innych, nowych sposobów przełamywania i przekraczania tradycyjnych wzorów teatru dramatycznego, do dziś stanowiącego podstawę teatralnej działalności, szybko zostało uznane za największe dokonanie organizacyjne jej toruńskiej dyrekcji, nie tylko w Polsce, ale i za granicą: otrzymała Paszport „Polityki” za „festiwal Kontakt, znakomicie podtrzymujący kontakt teatru polskiego ze światem - bliższym i dalszym” oraz Feliksa, nagrodę Gazety Wyborczej za zorganizowanie Międzynarodowego Festiwalu Teatralnego „Kontakt”. Uznanie to utorowało Meissner drogę do stanowiska dyrektora Starego Teatru im. Heleny Modrzejewskiej w Krakowie - od lat 70. pierwszej sceny w kraju.

Niestety, Krystyna Meissner, mając po swojej stronie najwybitniejszych reżyserów pracujących dla krakowskiej sceny, z Andrzejem Wajdą na czele - niemal od początku natrafiła na opór krakowskiego środowiska aktorskiego i związków zawodowych. Po półtora roku musiała z dyrekcji Starego Teatru zrezygnować. Zapytana w tej sytuacji przez dziennikarzy: „Czy żałuje Pani decyzji o odejściu z Teatru im. Wilama Horzycy w Toruniu i festiwalu Kontakt?”, odpowiedziała: - „Tak, teraz widzę, że popełniłam błąd” (Meissner 1998).

Po nieudanych sezonach krakowskich Krystyna Meissner objęła w roku 1999 stanowisko dyrektora Teatru Współczesnego we Wrocławiu, które pełniła przez trzynaście lat do przejścia na emeryturę w roku 2012. W swojej działalności dyrektorskiej i reżyserskiej rozwijała najlepsze tradycje dyrekcji Edmunda Wiercińskiego, Andrzeja Witkowskiego i Kazimierza Brauna, a ponadto powołała do życia w 2001 roku Międzynarodowy Festiwal Teatralny DIALOG, do dziś uznawany za najlepszy tego rodzaju festiwal w Polsce. 


\section{Bibliografia}

Babel, Izaak 1964. Zmierzch. W: Idem. Utwory wybrane. Warszawa: Czytelnik.

Butkiewicz, Zenon 2000. „Wspólnota teatralna Polski Północnej”. W: Janusz Skuczyński (red.). 80 lat teatru w Toruniu 1920-2000. Toruń: Wydawnictwo UMK.

Churski, Andrzej 1996. „Księżyc nad Londynem”. Nowości 32.

Csató, Edward 1960. Szkice o dramatach Słowackiego. Warszawa: PIW.

Fik, Marta 1989. „Odkrywanie Balladyny”. W: Eadem. Przeciw, czyli za. Warszawa: Czytelnik.

Hofman, J. 1985. „Teatr i Krystyna Meissner”. Scena 12.

Jagodzińska, Joanna, Marzenna Wiśniewska 2000. „Dziesięć lat Kontaktu (1991-2000): wokół idei i formuly Międzynarodowego Festiwalu w Toruniu”. W: Janusz Skuczyński (red.). 80 lat teatru w Toruniu. Toruń: Wydawnictwo UMK.

Konwicki, Tadeusz 1991. Mała Apokalipsa. Warszawa: Czytelnik.

Majcherek, Wojciech 1997. „Stoją jak pośnięci”. Teatr 4.

Meissner, Krystyna 1983. „Rozmowa K. Meissner z A. Walczak”. Nowości 182.

— 1984. „Rozmowa Krystyny Meissner z A. Churskim”. Nowości 40.

- 1991. „Rozmowa K. Meissner z P. Głuchowskim”. Gazeta Regionalna 64.

- 1992a. „Rozmowa K. Meissner z J. Oleradzką”. Gazeta Pomorska 226.

- 1992b. „Rozmowa z K. Meissner. Prowadził J. L Ordan”. Przegląd Artystyczno-Literacki 3.

- 1994a. „Rozmowa K. Meissner z S. Łopatyńskim”. Gazeta Regionalna 108.

— 1994b. „Rozmowa K. Meissner z K. Taras”. Przegląd Artystyczno-Literacki 5.

— 1995. „Rozmowa z Krystyną Meissner, Krzysztof Jędrys”. Głos Uczelni 10.

— 1998. „Spadochroniarka z Torunia. Rozmowa K. Meissner z B. Kamńskim i T. Mościckim”. Życie 144.

Mendelewska, Beata 1997. „'Wesele’ bez drugiego czaru”. Głos Uczelni 2.

Oleradzka, Jadwiga 1983. „Świątynia złudzeń”. Gazeta Pomorska 305.

- 1984. „Opera za dwa złote”. Gazeta Pomorska 246.

Osińska, Katarzyna 2000. „Rosjanie na toruńskim festiwalu Kontakt. Przywracanie kontaktów”. W: Janusz Skuczyński (red.). 80 lat teatru w Toruniu. Toruń: Wydawnictwo UMK.

Pawłowski, Roman 2003. „Sceny z życia prowincji: Krystyna Meissner”. Wysokie Obcasy 232.

Słowacki, Juliusz 1952. Dzieła. T. V i VII. Julisz Krzyżanowski (red.). Wrocław: Zakład Narodowy im. Ossolińskich.

- 1962. Korespondencja Juliusza Stowackiego. T. I. Eugeniusz Sawrymowicz (oprac.). Wrocław: Zakład Narodowy im. Ossolińskich.

Skuczyński, Janusz 1994. „Toruńska zemsta na drogach teatralnej tradycji”. Przegląd ArtystycznoLiteracki 5.

Stuczyńska, Teresa 1985. „Balladyna’ Krystyny Meissner na tle dotychczasowych inscenizacji dramatu Słowackiego”. Praca magisterska napisana pod kierunkiem prof. dra Artura Hutnikiewicza (mps). Toruń: UMK.

Wiadomości Kulturalne 1994. Wiadomości Kulturalne 13. 